\title{
Genetic Analysis of the Organization, Development, and Plasticity of Corneal Innervation in Mice
}

\author{
Dacim Bouheraoua, ${ }^{1,2}$ Stéphane Fouquet, ${ }^{1}$ Maria Teresa Marcos-Almaraz, ${ }^{1}$ Domna Karagogeos, ${ }^{3}$ \\ Laurent Laroche, ${ }^{1,2}$ and ${ }^{-}$Alain Chédotal ${ }^{1}$ \\ ${ }^{1}$ Institut de la Vision, Sorbonne Université, Institut National de la Santé et de la Recherche Médicale, Centre National de la Recherche Scientifique, F-75012 \\ Paris, France, ${ }^{2}$ Quinze-Vingts National Ophthalmology Hospital, Sorbonne Université, DHU Sight Restore, Institut National de la Santé et de la Recherche \\ Médicale-DGOS CIC 1423, F-75012 Paris, France, and 'Department of Basic Science, Faculty of Medicine, University of Crete, Vassilika Vouton, Crete 71110 , \\ Greece
}

The cornea has the densest sensory innervation of the body, originating primarily from neurons in the trigeminal ganglion. The basic principles of cornea nerve patterning have been established many years ago using classic neuroanatomical methods, such as immunocytochemistry and electrophysiology. Our understanding of the morphology and distribution of the sensory nerves in the skin has considerably progressed over the past few years through the generation and analysis of a variety of genetically modified mouse lines. Surprisingly, these lines were not used to study corneal axons. Here, we have screened a collection of transgenic and knockin mice (of both sexes) to select lines allowing the visualization and genetic manipulation of corneal nerves. We identified multiple lines, including some in which different types of corneal axons can be simultaneously observed with fluorescent proteins expressed in a combinatorial manner. We also provide the first description of the morphology and arborization of single corneal axons and identify three main types of branching pattern. We applied this genetic strategy to the analysis of corneal nerve development and plasticity. We provide direct evidence for a progressive reduction of the density of corneal innervation during aging. We also show that the semaphorin receptor neuropilin-1 acts cell-autonomously to control the development of corneal axons and that early axon guidance defects have long-term consequences on corneal innervation.

Key words: aging; corneal innervation; confocal microscopy; cornea; mouse genetics; neuropilin

\section{Significance Statement}

We have screened a collection of transgenic and knockin mice and identify lines allowing the visualization and genetic manipulation of corneal nerves. We provide the first description of the arborization pattern of single corneal axons. We also present applications of this genetic strategy to the analysis of corneal nerve development and remodeling during aging

\section{Introduction}

The somatosensory system conveys a variety of stimuli, such as pressure, temperature, and pain, transmitted to the CNS by a myriad of sensory axons that project to most organs, including

Received June 2, 2018; revised 0ct. 5, 2018; accepted Nov. 24, 2018.

Author contributions: N.B., S.F., M.T.M.-A., D.K., L.L., and A.C. edited the paper; A.C. wrote the first draft of the paper. N.B. and A.C. designed research; N.B., S.F., and M.T.M.-A. performed research; N.B., D.K., and A.C. contributed unpublished reagents/analytic tools; N.B., S.F., and A.C. analyzed data; N.B. and A.C. wrote the paper.

This work was supported by the Institut de Recherche Ophtalmologique de Paris to N.B. We thank Dr. Jean Livet for providing the Brainbow line and David Ginty for providing the CGRP:GFP, MrgprD:GFP, Split:cre, Npy2r:GFP, TrkB:TauGFP, VGlut3:GFP, and Ret:creERT2 mouse lines.

The authors declare no competing financial interests.

Correspondence should be addressed to Alain Chédotal at alain.chedotal@inserm.fr or Nacim Bouheraoua at nacim.bouheraoua@gmail.com.

https://doi.org/10.1523/JNEUROSCI.1401-18.2018

Copyright $(2019$ the authors $\quad 0270-6474 / 19 / 391150-19 \$ 15.00 / 0$ the skin. The cornea epithelium receives sensory inputs via the ophthalmic branch of the trigeminal nerve and is the densest innervated tissue at the surface of the body (Rózsa and Beuerman, 1982; Marfurt et al., 1989; Müller et al., 2003; Belmonte et al., 2015). The cornea is also innervated by autonomic axons coming from the ciliary and superior cervical ganglia, representing only $5 \%-10 \%$ of the corneal axons (Marfurt and Ellis, 1993).

The properties and organization of corneal nerves have been studied for decades with a wide range of techniques. Electrophysiological studies have shown that the cornea is innervated by $\mathrm{A}-\delta$ (myelinated) and C-fiber (unmyelinated) afferents (Lele and Weddell, 1959) comprising three functional classes: pure mechanonociceptors, cold sensing neurons, and polymodal nociceptors (Belmonte et al., 1991; González-González et al., 2017) responding to various noxious stimuli (mechanical, thermal, and chemical). Corneal axons have been visualized in humans and mice using Golgi staining, axonal tracing, lectin binding (Zander and 


\begin{tabular}{|c|c|c|c|c|}
\hline & Host & Vendor & Catalog no. (RRID no.) & Concentration \\
\hline \multicolumn{5}{|l|}{ Primary antibodies } \\
\hline Anti- $\beta$ III-tubulin & Rabbit & Covance & PRB-435P-100 (AB_291637) & $1: 1000$ \\
\hline Anti-CGRP & Rabbit & Peninsula & T-4032 (AB_2313775) & $1: 1000$ \\
\hline Anti-GFP & Rabbit & Invitrogen & A-11122 (AB_221569) & 1:1000 \\
\hline Anti- $\beta$ gal & Rabbit & MP Biochemicals & ab6645 (AB_2313831) & $1: 500$ \\
\hline IB4 & & Sigma & L2140 (AB_2313663) & 1:100 \\
\hline Anti-NF200 & Chicken & Aves Labs & NF-H (AB_2313552) & $1: 1000$ \\
\hline Anti-Tag-1 & Goat & R\&D Systems & AF1714 (AB_2245173) & $1: 1000$ \\
\hline \multicolumn{5}{|l|}{ Secondary antibodies } \\
\hline Anti-rabbit DyLight 488 & Donkey & Jackson ImmunoResearch Laboratories & 711-485-152 (AB_2492289) & 1:500 \\
\hline Anti-rabbit Cy-3 & Donkey & Jackson ImmunoResearch Laboratories & 711-166-152 (AB_2313568) & $1: 500$ \\
\hline Anti-rabbit Cy-5 & Donkey & Jackson ImmunoResearch Laboratories & 711-175-152 (AB_2340607) & $1: 500$ \\
\hline Anti-rabbit Alexa Fluor 488 & Donkey & Invitrogen & A-21206 (AB_141708) & $1: 500$ \\
\hline Anti-rabbit Alexa Fluor 594 & Donkey & Invitrogen & A-21207 (AB_141637) & $1: 500$ \\
\hline Anti-rabbit Alexa Fluor 647 & Donkey & Invitrogen & A-31573 (AB_2536183) & $1: 500$ \\
\hline Anti-goat Alexa Fluor 488 & Bovine & Jackson ImmunoResearch Laboratories & 805-545-180 (AB_2340883) & $1: 500$ \\
\hline Anti-goat Cy-3 & Bovine & Jackson ImmunoResearch Laboratories & 805-165-180 (AB_2340880) & $1: 500$ \\
\hline Anti-goat Alexa Fluor 647 & Bovine & Jackson ImmunoResearch Laboratories & 805-605-180 (AB_2340885) & $1: 500$ \\
\hline Anti-chicken Alexa Fluor 488 & Donkey & Jackson ImmunoResearch Laboratories & 703-545-155 (AB_2340375) & $1: 500$ \\
\hline Anti-chicken Cy-3 & Donkey & Jackson ImmunoResearch Laboratories & 703-165-155 (AB_2340363) & $1: 500$ \\
\hline Anti-chicken Cy-5 & Donkey & Jackson ImmunoResearch Laboratories & 703-175-155 (AB_2340365) & $1: 500$ \\
\hline Alexa 488-conjugated Streptavidin & & Thermo Fisher Scientific & S11223 (AB_2336881) & $1: 500$ \\
\hline
\end{tabular}

Weddell, 1951; Marfurt, 1988; de Castro et al., 1998), as well as noninvasive confocal laser scanning microscopy (Reichard et al., 2014; Ehmke et al., 2016). More recently, evidence for a higher diversity of corneal nerves has emerged through the characterization of receptors transducing the various sensory modalities in corneal axons, such as TRPV1 and TRPA1 (transient receptor potential cation channels subfamilies $\mathrm{V}$ or $\mathrm{A}$, member 1) for heat and chemical agents (Caterina et al., 1997; Nakamura et al., 2007; Canner et al., 2014; Alamri et al., 2015), Piezo2 for mechanical forces (Coste et al., 2010; Bron et al., 2014; Ranade et al., 2014), and TRPM8 (transient receptor potential cation channel subfamily M member 8) for cold (Bautista et al., 2007; Parra et al., 2010; Quallo et al., 2015). A few markers of corneal nerves have been validated with immunolabeling procedures, such as anti- $\beta$ IIItubulin or anti-PGP95, which recognize all types of corneal axons, or anti-CGRP, which only label some specific subsets (Marfurt et al., 2001; Murata and Masuko, 2006; Shimizu et al., 2007; Alamri et al., 2015). However, the analysis of the respective distribution and morphology of the different type of axons mediating different modalities, their development and responses to injury has been hampered by technical problems, such as an incomplete antibody penetration in the thickness of the cornea.

Recently, huge progress has been made in our understanding of the sensory innervation of the hairy skin through the use of genetically modified mouse lines expressing fluorescent proteins or Cre recombinase, in specific subsets of axons (Abraira and Ginty, 2013; Le Pichon and Chesler, 2014; Rutlin et al., 2014; Zimmerman et al., 2014). Surprisingly, only two transgenic lines have been used so far to study corneal nerves and few corneal nerve-cre lines have been described ( $\mathrm{Yu}$ and Rosenblatt, 2007; Parra et al., 2010; Namavari et al., 2011; Omoto et al., 2012). Here, we have screened a collection of transgenic and knockin mice to identify lines allowing the visualization and genetic manipulation of corneal nerves.

\section{Materials and Methods}

Mouse lines

Mice of either sex were used. All lines were previously described and were

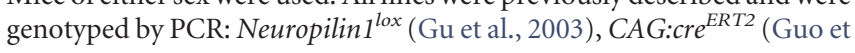

al., 2002), En1:cre (Kimmel et al., 2000), Islet1:cre (Yang et al., 2006), Ret:cre ${ }^{E R T 2}$ (Luo et al., 2009), Split:cre (Rutlin et al., 2014), TAG-1:cre (Schmidt et al., 2014), Wnt1:cre (Danielian et al., 1998), CGRP:GFP (Gong et al., 2003), MrgprD:GFP (Zylka et al., 2005), Npy2r:GFP (Li et al., 2011), Rosa $a^{\text {tdTomato }}$ (Madisen et al., 2010), Tau ${ }^{G F P}$ (Hippenmeyer et al., 2005), Tau ${ }^{\text {Syn-GFP }}$ (Esposito et al., 2014), Thy1:Brainbow1.0 (Livet et al., 2007), TrkB:TauGFP (Li et al., 2011), and VGlut3:GFP (Seal et al., 2009). WT mice were from the C57BL6 background (Janvier). Compound mutants were obtained by intercrossing the various lines. The day of the vaginal plug was counted as E0.5, and the day of the birth as postnatal day 0 (P0). All animal procedures were performed in accordance with the European Community Council directive (86/609/EEC) for the care and use of laboratory animals and approved by the Sorbonne Université ethics committee (comité Charles Darwin).

\section{Tamoxifen administration}

Adult (2 month-old) Ret:cre ${ }^{E R} ;$ Rosa $^{T o m}$, Ret:cre $^{E R} ;{ }^{T a u}{ }^{G F P}$, Ret:cre $^{E R}$; Rosa $^{\text {Tom }} ;$ Tau $^{G F P}$, Ret:cre $^{E R} ;$ Rosa $^{\text {Tom }} ;$ CGRP:GFP, and CAG:Cre ${ }^{\text {ERT2 }}$;Thy1Brainbow1.0 mice were injected intraperitoneally with a single dose (ranging from 0.25 to $3 \mathrm{mg}$ ) of tamoxifen (Sigma-Aldrich, T-5648) dissolved in corn oil (Sigma-Aldrich, C-8267). Animals were perfused and tissue collected 14-60 d later. P0 pups of CAG:cre ${ }^{E R T 2}$;Thy1-Brainbow1.0 were subcutaneously injected with $0.3 \mathrm{mg}$ of tamoxifen.

\section{Immunohistochemistry}

The primary and secondary antibodies used are listed in Table 1.

Cornea. Mice were killed, and the eyeballs were enucleated and fixed in freshly prepared 4\% PFA for $15 \mathrm{~min}$. Next, the corneas were carefully excised along the sclerocorneal rim and fixed for an additional $45 \mathrm{~min}$, followed by three washes with PBS. To block nonspecific binding, corneas were placed in a 96-well plate (one cornea/well) and then incubated with $0.2 \%$ gelatin in PBS containing 0.5\% Triton X-100 (Sigma-Aldrich) for $60 \mathrm{~min}$ at room temperature. The tissue was then incubated with primary antibodies for $72 \mathrm{~h}$ at room temperature. After washing with PBS, the corneas were incubated in species-specific secondary antibodies directly conjugated to fluorophores (Table 1 ) for $24 \mathrm{~h}$ at room temperature and then washed thoroughly with $0.1 \mathrm{M}$ PBS.

Corneas were examined using a fluorescent microscope (DM6000, Leica Microsystems) equipped with a CoolSnapHQ camera (Princeton Instruments) or a confocal microscope (FV1000, Olympus). Brightness and contrast were adjusted using Photoshop CS6 software (Adobe, RRID:SCR_014199). 
Trigeminal ganglia. Adult mice were anesthetized with ketamine (50 $\mathrm{mg} / \mathrm{kg}$ ) and xylazine ( $10 \mathrm{mg} / \mathrm{kg})$ intraperitoneally and perfused using $4 \%$ PFA in $0.1 \mathrm{M} \mathrm{PB}, \mathrm{pH}$ 7.4. The crania was opened, and both left and right trigeminal ganglia were removed and fixed in freshly prepared 4\% PFA for $1 \mathrm{~h}$, followed by three washes with $0.1 \mathrm{M}$ PBS. Samples were cryoprotected in a solution of $10 \%$ sucrose in $0.12 \mathrm{~m}$ phosphate buffer, $\mathrm{pH} 7.2$, frozen in isopentane at $-50^{\circ} \mathrm{C}$, and then cut at $20 \mu \mathrm{m}$ with a cryostat (Leica Microsystems). Immunohistochemistry was performed on cryostat sections after blocking in $0.2 \%$ gelatin in PBS containing $0.25 \%$ Triton X-100 (Sigma-Aldrich). Sections were then incubated overnight at room temperature with the primary antibodies (Table 1). After washing with PBS, the sections were incubated at room temperature in species-specific secondary antibodies directly conjugated to fluorophores for $2 \mathrm{~h}$ and then washed thoroughly with $0.1 \mathrm{M}$ PBS. Nuclei were counterstained using DAPI (1:1000; Thermo Fisher Scientific). Sections were examined using a fluorescent microscope (DM6000, Leica Microsystems) equipped with a CoolSnapHQ camera (Princeton Instruments), a confocal microscope (FV1000, Olympus), or a slide scanner (Nanozoomer, Hamamatsu). Brightness and contrast were adjusted using Photoshop CS6 software (Adobe).

\section{Confocal microscope acquisition}

Imaging. Cornea image stacks were acquired with an FV1000 laserscanning confocal microscope (Olympus). The objectives used were an Olympus UPLSAPO $4 \times$ NA 0.16 WD 13, UPLSAPO $10 \times$ NA 0.4 WD 3.1, XLUMPPLFL $10 \times$ NA 0.6 WD 3.1, UPLSAPO 20× NA 0.85 WD 0.20, UPLFLN $40 \times$ NA 1.30 WD 0.20, PLAPON $60 \times$ SC NA 1.40 WD 0.12, or UPLSAPO $100 \times$ NA 1.4 WD 0.13 .

DAPI, eCFP, AlexaFluor-594 (or RFP), AlexaFluor-647, and AlexaFluor-488 (or eGFP), eYFP were excited using 405, 440, 559, and $635 \mathrm{~nm}$ laser diodes lines and $488-515 \mathrm{~nm}$ argon ion laser lines, respectively. Controls of the microscope and image acquisition were conducted with Fluoview software version 4.2 (Olympus). Image acquisition was conducted at a resolution of $1024 \times 1024$ pixels, with a scan rate of $8-10$ $\mu \mathrm{s} /$ pixel, with or without zoom. Images were acquired sequentially, line by line, to reduce excitation and emission crosstalk; step size was defined according to the Nyquist-Shannon sampling theorem. Exposure settings that minimized oversaturated pixels in the final images were used. When acquiring images to be stitched, the MATL module from Fluoview software was used to program $10 \%$ overlap between each tile. Montage was then processed using Fluoview software or ImageJ stitching plugins (Preibisch et al., 2009).

Image processing. To change orientation and to obtain a sagittal view of the stacks, a resampling was processed using the reslice option of ImageJ software. Twelve-bit images were processed with ImageJ (RRID: SCR_003070) or FIJI (RRID:SCR_002285). $Z$ sections were projected on a single plane using maximum intensity under $Z$-project function. Images were finally converted into 24 bits RGB color mode, and figures were then assembled by using Photoshop CS6 (Adobe). To improve contrast, a negative image of the fluorescent axons was sometimes generated using Photoshop (Adobe) or Imaris software (version 8.4.1, Bitplane). In this case, axons appeared in black on a white background.

For $3 \mathrm{D}$ rendering, images were generated using Imaris. Stack images were first converted to imaris file format (.ims) using ImarisFileConverter, and 3D reconstruction was performed using the "volume rendering" function. To facilitate image processing, images were converted to an 8-bit format. Optical slices were obtained using the "orthoslicer" tool. 3D pictures were generated using the "snapshot" tools.

Automated tracking of cornea nerves. The Imaris filament tracer tool was used to draw and isolate unique axons on confocal images. Filaments were first rendered by manually selecting a dendrite starting point; the filaments were then traced and volume rendered using the AutoDepth algorithm and represented as cylinders ( $2 \mu \mathrm{m} /$ filament $)$. Following this tracing step, cornea nerve morphology was observed, tracing comptabilized, and different type of nerve terminals were classified.

\section{DISCO tissue clearing and 3D light sheet microscopy}

Embryos. Whole embryos were fixed by immersion in 4\% PFA overnight at $4^{\circ} \mathrm{C}$. Samples were first incubated at room temperature on a rotating shaker in a solution (PBSGT) of PBS $1 \times$ containing $0.2 \%$ gelatin (Prolabo), $0.5 \%$ Triton X-100 (Sigma-Aldrich), and $0.01 \%$ thimerosal (Sigma-Aldrich) for $3 \mathrm{~h}$. Samples were next transferred to PBSGT containing the primary antibody (goat anti-Tag-1; 1:500; R\&D Systems) and placed at $37 \mathrm{C}^{\circ}$, with rotation at $100 \mathrm{rpm}$, for $3 \mathrm{~d}$. This was followed by six washes of $30 \mathrm{~min}$ in PBSGT 0.5\% at room temperature. Next, samples were incubated in secondary antibodies diluted in PBSGT 0.5\% (Table 1) overnight at room temperature. After six washes of $30 \mathrm{~min}$ in PBSGT $0.5 \%$, samples were stored at $4^{\circ} \mathrm{C}$ in PBS until clearing.

3DISCO clearing. For tissue clearing, a modified 3DISCO protocol was used (Belle et al., 2014). First, embryos were fixed by immersion in $4 \%$ PFA in $0.12 \mathrm{M} \mathrm{PB}, \mathrm{pH} 7.4$ (PFA) overnight at $4^{\circ} \mathrm{C}$. All incubation steps were performed in dark conditions at room temperature in a fume hood, on a tube rotator (SB3, Stuart) at $14 \mathrm{rpm}$, using a $15 \mathrm{ml}$ centrifuge tube (TPP, Dutscher). Samples were first dehydrated in ascending concentrations $(50 \%, 80 \%$, and $100 \%)$ of tetrahydrofuran (anhydrous, containing $250 \mathrm{ppm}$ butylated hydroxytoluene inhibitor, Sigma-Aldrich) diluted in $\mathrm{H}_{2} \mathrm{O}$. The initial $50 \%$ tetrahydrofuran bath was done overnight while the $80 \%$ and $100 \%$ tetrahydrofuran incubations were left for $1.5 \mathrm{~h}$ each. Samples next underwent a delipidation step of $30 \mathrm{~min}$ in dichloromethane (Sigma-Aldrich) followed by an overnight clearing step in dibenzyl ether (Sigma-Aldrich). The next day, samples were stored in individual light-absorbing glass vials (Rotilabo, Carl Roth) at room temperature.

$3 D$ imaging. Acquisitions were performed using a light sheet fluorescence microsope (Ultramicroscope $\mathrm{I}$, LaVision BioTec) with the InspectorPro software ( $\mathrm{LaVision} \mathrm{BioTec})$. The light sheet was generated by a laser ( $640 \mathrm{~nm}$ wavelength, Coherent Sapphire Laser, LaVision BioTec) and focused using two cylindrical lenses. Two adjustable protective lenses were applied for small and large working distances. A binocular stereomicroscope (MXV10, Olympus) with a $2 \times$ objective (MVPLAPO, Olympus) was used at $2.5 \times$ and $3.2 \times$. Samples were placed in an imaging reservoir made of $100 \%$ quartz (LaVision BioTec) filled with dibenzyl ether and illuminated from the side by the laser light. A PCO Edge SCMOS CCD camera $(2560 \times 2160$ pixel size, LaVision BioTec $)$ was used to acquire images. The step size between each image was fixed at 1 and $2 \mu \mathrm{m}$. All tiff images are generated in 16 bits.

\section{Experimental design and statistical analysis}

Statistical analyses of the mean and variance were performed with Prism 7 (GraphPad Software; RRID:SCR_002798). Mice of either sex were used throughout the studies. Results are presented as mean \pm SD for continuous variables and as proportions (\%) for categoric variables. The Kruskal-Wallis test and the Mann-Whitney test were used to compare continuous data as appropriate. The nerve fiber length was calculated as the total length nerve fibers and branches on a maximal projection of the ultramicroscope image. Quantification was performed using NeuronJ (RRID:SCR_002074), a semiautomated nerve analysis plug-in program of ImageJ. Fiber density was quantified by measuring pixel density in a cornea field of $300 \mu \mathrm{m} \times 300 \mu \mathrm{m}$ (corresponding to a $40 \times$ objective) using ImageJ. In some cases, the epithelium and stroma were isolated using the orthoslicer tool of ImageJ, and next the density of corneal axons in each layer was quantified. The central zone was defined by a radius of $0.5 \mathrm{~mm}$ starting at the apex, and the peripheral zone with a radius of 0.5 $\mathrm{mm}$ beginning at the limbus. The structure of the cornea in Tag1:Cre; $N p n 1^{l o x}$ mice was studied using DAPI counterstaining. We used the cell counter tool and the measurement tool (ImageJ) to quantify the number of superficial epithelial cells, basal epithelial cells, and keratocytes and corneal thickness. Differences were considered significant when $p<0.05$.

\section{Results}

\section{A unique collection of transgenic lines for visualizing} corneal nerves

\section{CGRP:GFP line}

In the cornea of rodents, most peptidergic nociceptive C-fibers are immunoreactive for CGRP and almost two-thirds of trigeminal neurons are CGRP ${ }^{+}$(Jones and Marfurt, 1991; Ivanusic et al., 2013; He and Bazan, 2016). However, a comprehensive map 


\section{A}

CGRP:GFP BAC

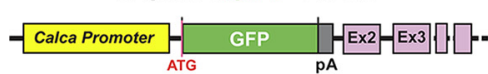
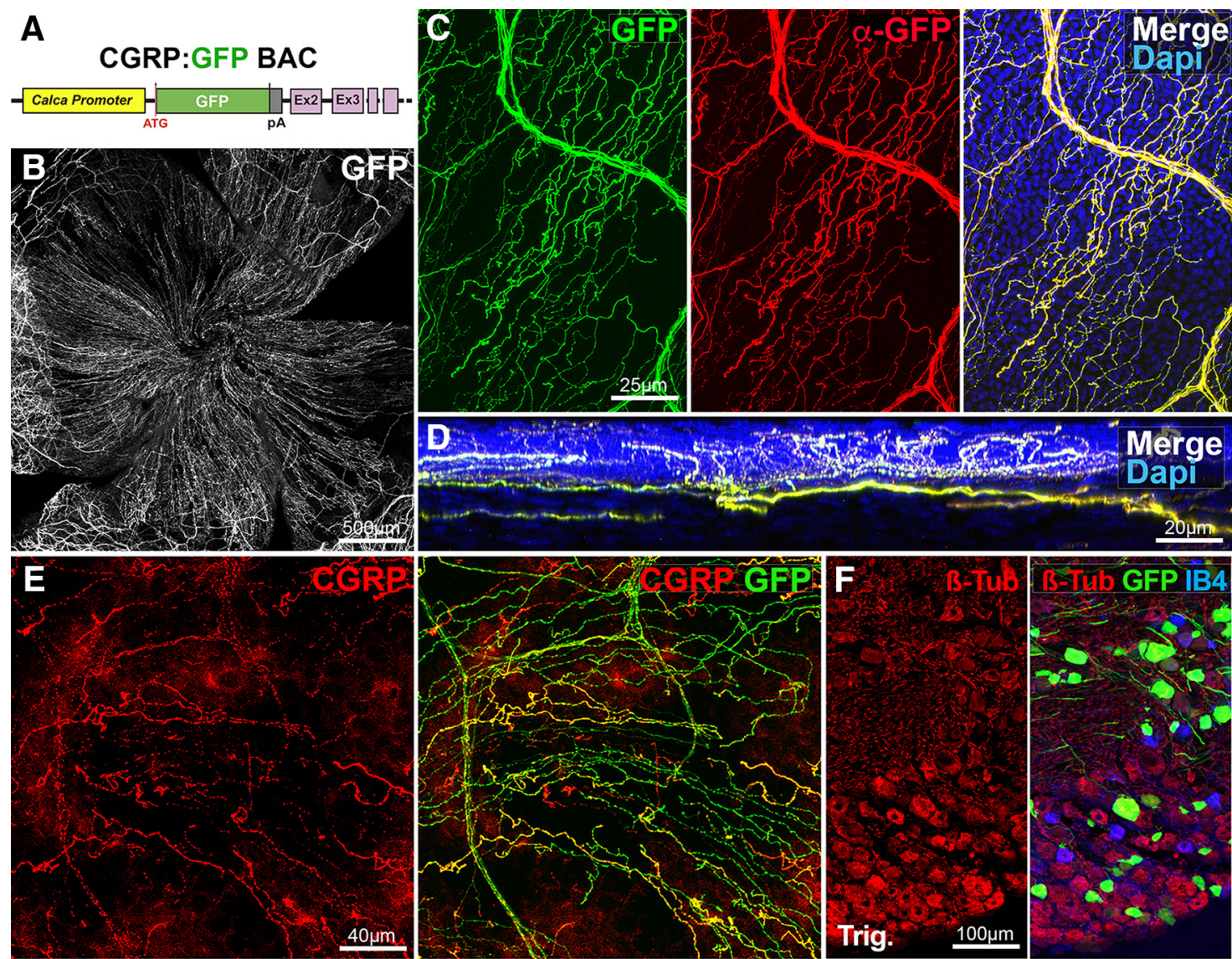

$40 \mu \mathrm{m}$.
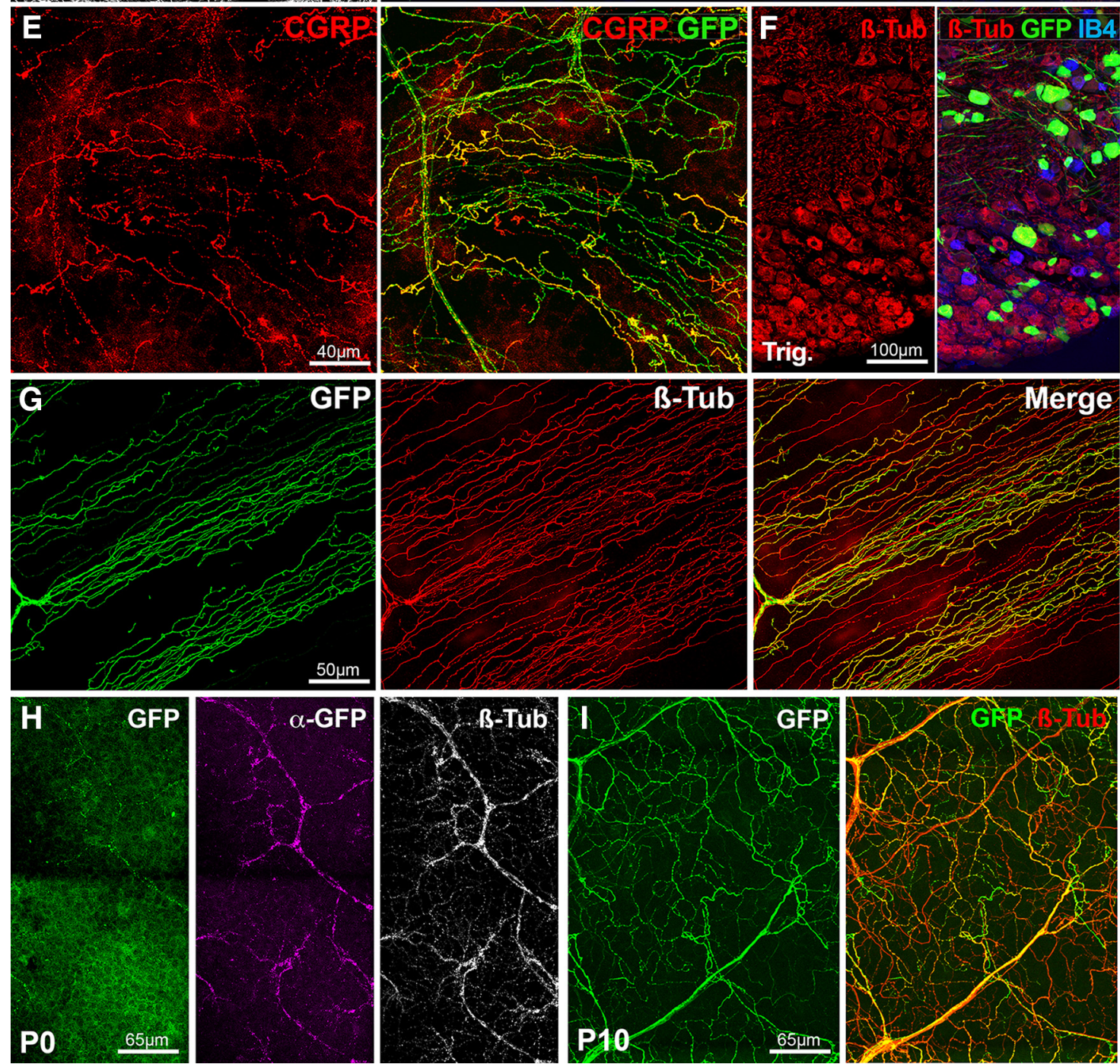

Figure 1. Visualization of corneal peptidergic axons in (GRP:GFP mice. All panels (except $\boldsymbol{D}$ and $\boldsymbol{F}$ ) are maximal intensity z-projection confocal stacks from whole-mount corneas. $\boldsymbol{A}$, Schematic of the CGRP:GFP BAC transgenic construct. GFP was inserted downstream the promoter of the Calca gene, which encodes CGRP. $\boldsymbol{B}-\boldsymbol{G}$, Images from adult CGRP:GFP mice. $\boldsymbol{B}$, Flat mount view of a whole-mount cornea, showing GFP expression in corneal nerves. C, Cornea immunolabeled with anti-GFP with DAPI counterstaining (blue). There is a perfect overlap (merge) between the endogenous GFP fluorescence (green) and the anti-GFP immunoreactivity (red). D, A reslice of the cornea (54- $\mu \mathrm{m}$-thick optical section) showing the location of the GFP axons in the stroma, sub-basal plexus, and epithelium. $\boldsymbol{E}$, Cornea immunolabeled with anti-CGRP (red). All CGRP axons are also GFP ${ }^{+}$. $\boldsymbol{F}$, Cryostat section of the trigeminal ganglion stained with IB4 (blue) and immunolabeled for $\beta$ III-tubulin (red). GFP neurons only represent a subset of $\beta$ III-Tub ${ }^{+}$trigeminal neurons. G, Cornea immunolabeled with anti- $\beta$ III-tubulin (red). Typical corneal axon leashes of almost parallel GFP ${ }^{+}$axons (green) are seen. GFP is only expressed in a subset of corneal nerves. $\boldsymbol{H}$, At P0, the endogenous GFP expression is weaker than after anti-GFP immunostaining (magenta). All corneal axons in this domain can be seen with anti- $\beta$ III-tubulin immunostaining (white, right). I, GFP ${ }^{+}$axons in the P10 cornea immuno-labeled for $\beta$ III-tubulin. 

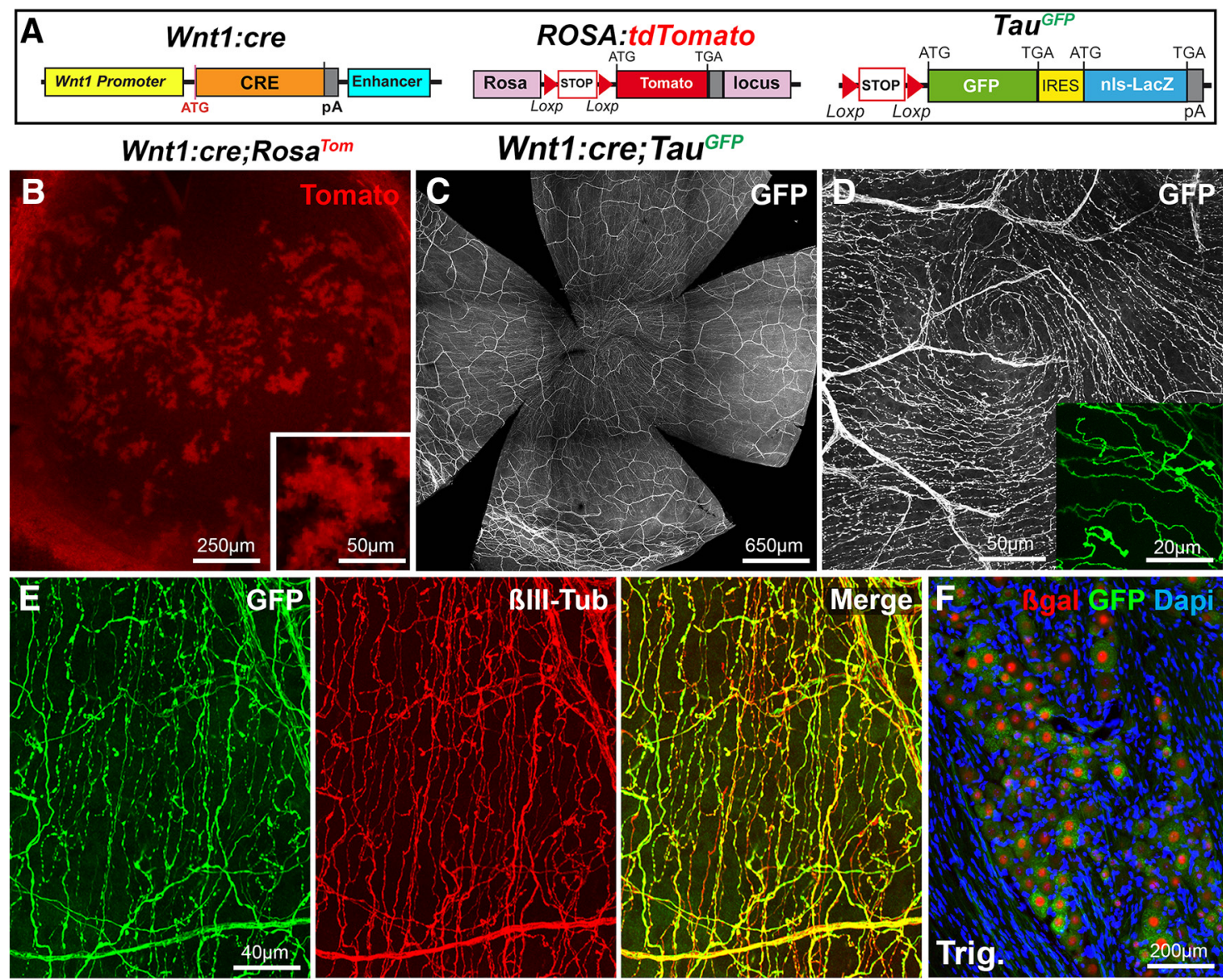

Wnt1:cre;Tau ${ }^{\text {Syn-GFP }}$

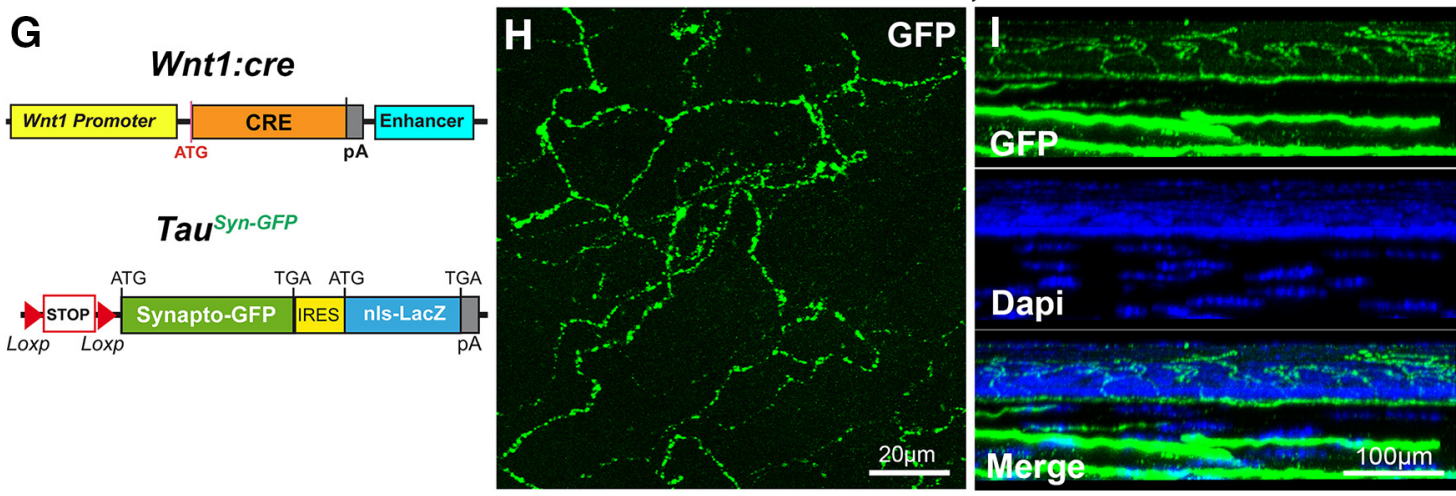

Figure 2. Visualization of corneal axons in Wnt1:cre mice. All panels (except $\boldsymbol{F}$ and $\boldsymbol{I}$ ) are maximal intensity z-projection confocal stacks from adult whole-mount corneas. $A$, Schematic description

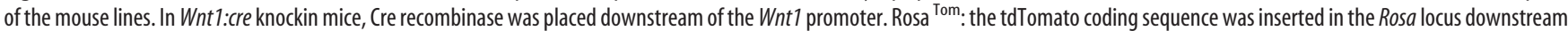
of a lox-STOP-lox cassette. In Tau ${ }^{G F P}$ mice, a lox-STOP-lox cassette preceding a myristoylated GFP sequence, followed by an Internal ribosome entry site (IRES) CDNA and the lacZ sequence with a nuclear localization signal (nls), was inserted by homologous recombination in the Tau locus. $\boldsymbol{B}$, Islets of corneal cells express Tomato (red) in Wnt1:cre:Rosa ${ }^{\text {Tom }}$ mice. C, D, The dense network of GFP ${ }^{+}$ corneal axons in Wnt1:Cre;Tau ${ }^{G F P}$ mice. The apical vortex is shown in $\boldsymbol{D}$. Inset, Terminal intraepithelial branches. $\boldsymbol{E}$, Cornea immunolabeled with anti- $\beta$ III-tubulin antibodies (red). GFP and $\beta$ III-tubulin nicely overlap. $\boldsymbol{F}$, Cryostat section of the trigeminal ganglion at the level of the ophthalmic V1 division stained DAPI (blue) and immunolabeled for $\beta$-galactosidase (red). GFP ${ }^{+}$ trigeminal neurons express $\beta$-gal in their nucleus. G, Description of the mouse lines. Wnt1:cre (see above). In Tau ${ }^{\text {Syn-GFP }}$ mice, a lox-STOP-lox cassette preceding a cDNA encoding Synaptophysin fused to GFP, followed by an Internal ribosome entry site (IRES) CDNA and the lacZ sequence with a nuclear localization signal (nls) was inserted by homologous recombination in the Tau locus. $\boldsymbol{H}$, Beaded appearance of the GFP signal in Wnt 1cre;Tau ${ }^{\text {SynGFP }}$ mice. I, A reslice of the cornea with DAPI counterstaining (blue).

of CGRP innervation in the mouse cornea was only recently generated using whole-mount immunostaining (Alamri et al., 2015; He and Bazan, 2016). To try visualizing $\mathrm{CGRP}^{+}$axons without immunostaining, we used a BAC transgenic (Fig. 1A; see Materials and Methods), which was previously shown to label C-fibers and a few $\mathrm{A} \beta$-low threshold mechanoreceptors (LTMRs) in the mouse hairy skin (Bai et al., 2015). Whole-mount corneas were dissected, flat-mounted, and imaged with a confocal microscope revealing a dense network of $\mathrm{GFP}^{+}$axons covering the cornea (Fig. $1 B ; n>30$ ). We next performed whole-mount immunolabeling of some corneas $(n=3)$ with anti-GFP antibodies to determine whether the endogenous GFP fluorescence signal faithfully reflected the population of axons expressing the reporter. Secondary antibodies coupled to Alexa-Cy3 were used to distinguish endogenous fluorescence from GFP immunostaining. Confocal imaging showed that direct GFP fluorescence sig- 

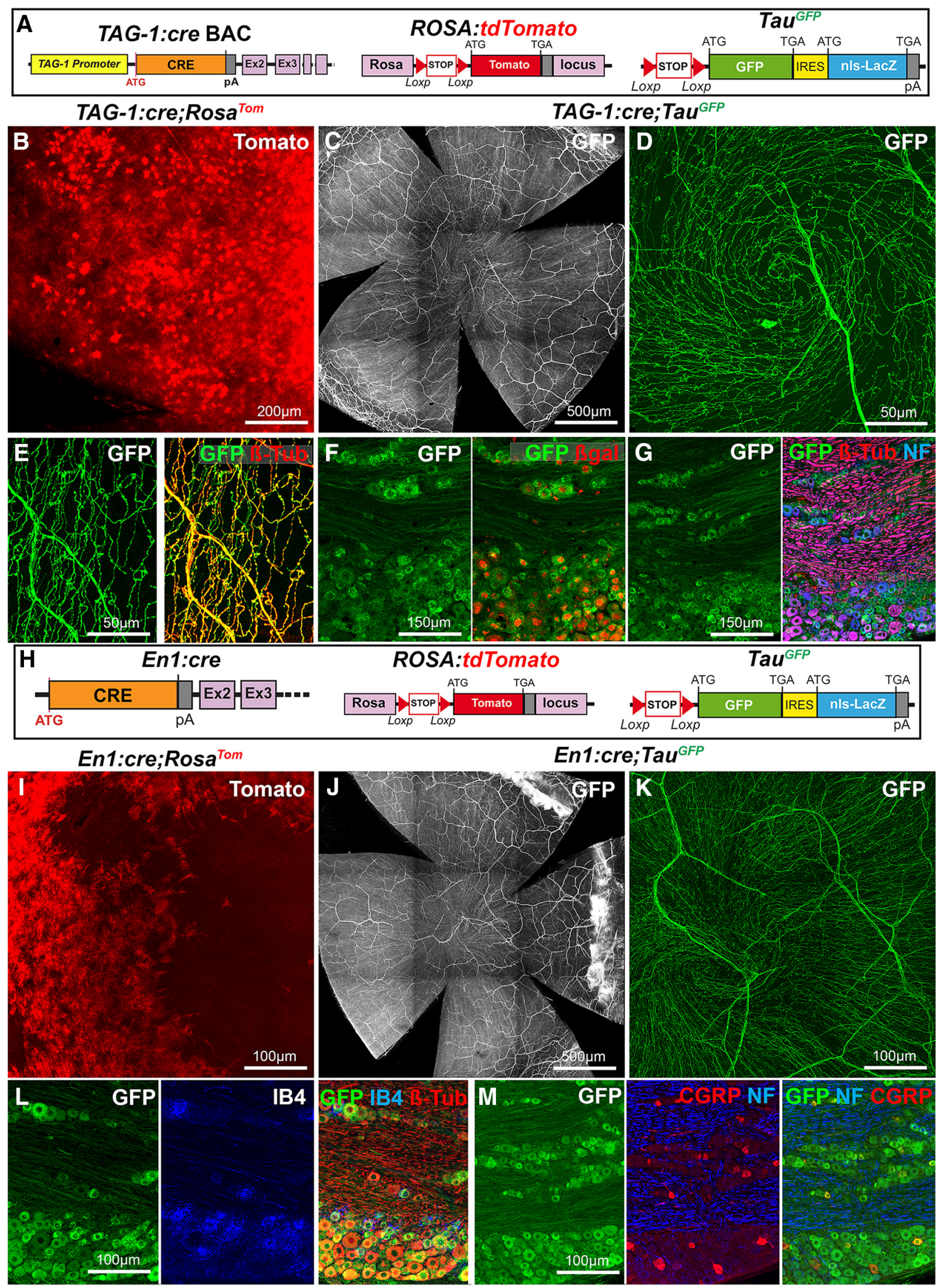

Figure 3. Visualization of corneal axons in TAG-1:cre and En1:cre adult mice. $\boldsymbol{B}-\boldsymbol{E}, \boldsymbol{I - K}$, Maximal intensity z-projection confocal stacks from adult whole-mount corneas. $\boldsymbol{F}, \boldsymbol{G}, \boldsymbol{L}, \boldsymbol{M}, \mathbf{C o n f o c a l}$ images of cryostat sections of trigeminal ganglia. $A$, Description of the mouse lines. Rosa ${ }^{\text {Tom }}$ and Tau ${ }^{G F P}$ (see Fig. 2). In the TAG-1-cre BAC transgenic construct, Cre recombinase was inserted downstream the promoter of the Tag-1/Cntn2 gene in an artificial chromosome. $\boldsymbol{B}$, Tomato is highly expressed by corneal cells in TAG-1:cre;Rosat ${ }^{\text {Tom }}$ mice. $\boldsymbol{C}, \mathbf{D}$, The dense network of GFP ${ }^{+}$corneal axons in TAG-1:cre; Tau ${ }^{G F P}$ mice. The apical vortex is shown in D. E, Cornea immunolabeled with anti- $\beta$ III-tubulin antibodies (red). GFP and $\beta$ III-tubulin perfectly overlap. (Figure legend continues.) 
nal perfectly matched the GFP immunostaining (Fig. 1C). Reslicing of the image stacks using ImageJ (see Materials and Methods) allowed following corneal nerves and axons in the stroma, sub-basal plexus to their arborizations and endings in the cornea epithelium (Fig. 1D). Whole-mount immunostaining for CGRP ( $n=3$ corneas) showed that all CGRP ${ }^{+}$axons coexpressed GFP (Fig. 1E). Some $\mathrm{GFP}^{+}$axons did not appear to be $\mathrm{CGRP}^{+}$, but this was probably due to the incomplete penetration of the anti-CGRP antibodies. Next, the trigeminal ganglia of CGRP:GFP mice $(n=5)$ was cut with a cryostat and immunostained with anti- $\beta$ III-tubulin, a pan-neuronal marker. As expected, this showed that only a subset of trigeminal neurons express GFP $(36 \pm 2.4 \%)$ (Fig. $1 F)$.

Accordingly, in corneas immunolabeled for $\beta$ III-tubulin, the $\mathrm{GFP}^{+}$axons only represented a fraction of the $\beta$ III-tubulin ${ }^{+}$ axons (Fig. $1 G$ ). CGRP $^{+}$fibers represent $64 \%$ of the $\beta$ IIItubulin ${ }^{+}$fibers in the center of the cornea $(94,060 \pm 14,684$ pixels $\mathrm{CGRP}^{+}$vs $146,351 \pm 27,062$ pixels $\left.\beta \mathrm{III}^{+}\right)$and $56 \%$ of the $\beta$ III-tubulin ${ }^{+}$fibers in the periphery of the cornea $(69,314 \pm$ 13,702 pixels $\mathrm{CGRP}^{+}$vs $123,187 \pm 14,238$ pixels $\beta \mathrm{III}^{+}$).

Finally, we found that CGRP ${ }^{+}$axons were significantly fewer in the periphery than in the center of the cornea $(p=0.04$; Mann-Whitney test) and represented approximately two-thirds of adult corneal axons consistently with previous studies (He and Bazan, 2016).

To determine whether the CGRP:GFP line could be used to study the development of corneal peptidergic axons, corneas from P0 and P10 CGRP:GFP mice were collected and doubleimmunostained for $\beta$ IIII-tubulin and GFP $(n=5$ and $n=8$, respectively). At $\mathrm{P} 0, \mathrm{GFP}^{+}$axons could be directly observed, but they were more numerous and more strongly labeled after antiGFP immunostaining (Fig. $1 H$ ), suggesting that transgene expression is weaker at birth than in adults. However, at P10, the endogenous GFP signal in corneal nerves appeared as intense as in adults (Fig. 1I). Both at $\mathrm{P} 0$ and $\mathrm{P} 10, \mathrm{GFP}^{+}$axons coexpressed $\beta$ III-tubulin, but they only represented a fraction of the corneal axons (Fig. $1 H, I$ ). Together, these data suggest that the dense network of nociceptive peptidergic C-fibers can be fully imaged using the CGRP:GFP line.

\section{Wnt1:cre line}

Genetic fate-mapping studies have demonstrated that sensory neurons in the trigeminal ganglia derive from the trigeminal placode and from neural crest cell progenitors in the dorsal neural tube (Steventon et al., 2014), expressing the Wnt1 transcription factor (Evans and Gage, 2005). The Wnt1:cre line was previously used to permanently label neural crest cell derivatives (Danielian et al., 1998; Gage et al., 2005). To try visualizing trigeminal neuron projections to the cornea, we crossed Wnt1:cre mice (Danielian et al., 1998) to two reporter lines (Fig. 2A). First, we use the Rosa26:tdTomato line (Rosa ${ }^{\text {Tom }}$ ) in which the red fluorescent protein Tomato is expressed upon Cre recombinase activity (Madisen et al., 2010). In corneas from Wnt1:cre;Rosa ${ }^{\text {Tom }}$ mice $(n=$

\section{$\leftarrow$}

(Figure legend continued.) $\quad \boldsymbol{F}, \mathbf{G}$, In the trigeminal ganglion, $\mathrm{GFP}^{+}$neurons express $\beta$-gal in

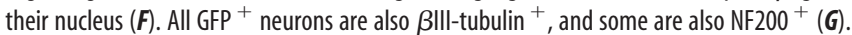
$\boldsymbol{H}$, Description of the mouse lines. Rosa ${ }^{T o m}$ and Tau ${ }^{G F P}$ (see Fig. 2). In En1:cre knockin mice, the first exon of the engrailed- 1 gene was replaced by the Cre sequence using homologous recombination. I, Tomato is highly expressed by a large fraction of corneal cells in En1:cre;Rosa ${ }^{\text {Tom }}$ mice. $J, \boldsymbol{K}_{,} \mathrm{GFP}^{+}$corneal axons in En1:cre;Tau ${ }^{G F P}$ mice. The apical vortex is shown in $\boldsymbol{K} . \boldsymbol{L}, \boldsymbol{M}$, In the trigeminal ganglion, all IB4 ${ }^{+}$and all $\beta$ III-immunoreactive neurons are GFP ${ }^{+}(\boldsymbol{L})$. GFP is also expressed in the $\mathrm{CGRP}^{+}$and $\mathrm{NF} 200^{+}$populations $(\boldsymbol{M})$.
2 ), numerous patches and islets of Tomato ${ }^{+}$cells were observed throughout the cornea (Fig. $2 B$ ). This is in agreement with earlier work indicating that most corneal cells have a neural crest cell origin. Fluorescent axons were not observed in the cornea. Second, we used the Tau-lox-Stop-lox-mGFP-IRES-nls-lacZ mice $\left(\right.$ Tau $\left.^{G F P}\right)$ in which Cre-mediated recombination leads to the permanent expression of a myristoylated GFP in axons and of $\beta$-galactosidase ( $\beta$-gal) in nuclei (Hippenmeyer et al., 2005), but only in cells expressing the Tau protein, such as neurons and oligodendrocytes (Hippenmeyer et al., 2005; Young et al., 2013). Confocal imaging of whole-mount corneas $(n>30)$ from $W n t 1$ : cre; $\mathrm{Tau}^{G F P}$ mice revealed a dense meshwork of GFP-positive axons (Fig. 2C), including large axonal bundles in the stroma, typical axonal leashes oriented in a centripetal direction, and fine intraepithelial branches (Fig. 2D). We also observed an almost perfect overlap between the GFP fluorescence and the $\beta$-III tubulin immunolabeling $(n=3)$, suggesting that the vast majority of corneal nerves were labeled in Wnt1:cre;Tau ${ }^{G F P}$ mice. This conclusion was further supported by the analysis of trigeminal ganglia sections in which neuronal nuclei (visualized with DAPI) also expressed $\beta$-gal (Fig. $2 F$ ). We also used another reporter line Tau-lox-Stop-lox-Syn-GFP-IRES-nls-lacZpA mice (Tau ${ }^{\text {Syn-GFP }}$ ) (Pecho-Vrieseling et al., 2009), in which Cre recombination results in the expression at presynaptic terminals of a fusion protein between the synaptic vesicle protein Synaptophysin and GFP (Fig. $2 G$ ). As in Wnt1:cre; Tau ${ }^{G F P}$ mice, a strong GFP expression was detected in the corneal nerves of Wnt1:cre; Tau ${ }^{\text {Syn-GFP }}$ mice (Fig. $2 H, I$ ). The concentration of the GFP at vesicular release sites (or varicosities) resulted in a beaded appearance of the GFP signal in the subepithelial plexus and the epithelium $(n=10)$.

These results show that the combination of Wnt1:cre and $T_{a u}^{G F P}$ and Tau ${ }^{\text {Syn-GFP }}$ lines probably allows visualization of the entire population of corneal nerves, most likely including autonomic axons, which also belong to the Wnt1/neural crest cell lineage (Espinosa-Medina et al., 2014).

\section{TAG-1:cre line}

TAG-1 (also known as Contactin-2) is a cell-adhesion molecule of the immunoglobulin superfamily (Furley et al., 1990). TAG-1 is expressed by various types of cells, including sensory neurons in the peripheral nervous system, retinal ganglion cells, oligodendrocytes, and Schwann cells (Furley et al., 1990; Traka et al., 2002; Chatzopoulou et al., 2008). Therefore, we thought that the recently described TAG-1:cre BAC transgenic line (Schmidt et al., 2014) could be used to visualize trigeminal projections (Fig. 3A). In TAG-1:cre; Rosa ${ }^{\text {Tom }}$ mice, a strong Tomato expression was induced in cornea cells (Fig. $3 B$ ) as observed in the Wnt1:cre; Rosa ${ }^{\text {Tom }}$ mice. However, at P0, Tomato expression in TAG-1:cre; $\operatorname{Rosa}^{\text {Tom }}$ was restricted to a few cells in the periphery of the cornea (data not shown). This suggests that TAG-1 expression in the neural crest cell progeny is not limited to Schwann cells but extend to the cornea. To bypass this problem, we again relied on the $\mathrm{Tau}^{G F P}$ line and found that most corneal axons strongly expressed GFP in the TAG-1:cre; Tau ${ }^{G F P}$ line (Fig. 3C,D; $n>30$ ), as confirmed by their coexpression of $\beta$ III-tubulin (Fig. $3 E ; n=3$ ). In trigeminal ganglion sections $(n=3)$ from TAG-1:cre; Tau ${ }^{G F P}$ mice, $\beta$ gal and GFP were coexpressed (Fig. $3 F$ ) and found in both Neurofilament 200-positive myelinated non-nociceptive axons and Neurofilament 200-negative nociceptive axons (Namavari et al., 2011). The presence of Neurofilament $200^{+}$axons in the mouse cornea has already been reported (Chucair-Elliott et al., 2015). 


\begin{tabular}{|l|l|l|l|l|}
\hline Islet1:cre & \multicolumn{3}{c|}{ ROSA:tdTomato } \\
\hline PA & Rosa & Loxp Loxp \\
\hline
\end{tabular}
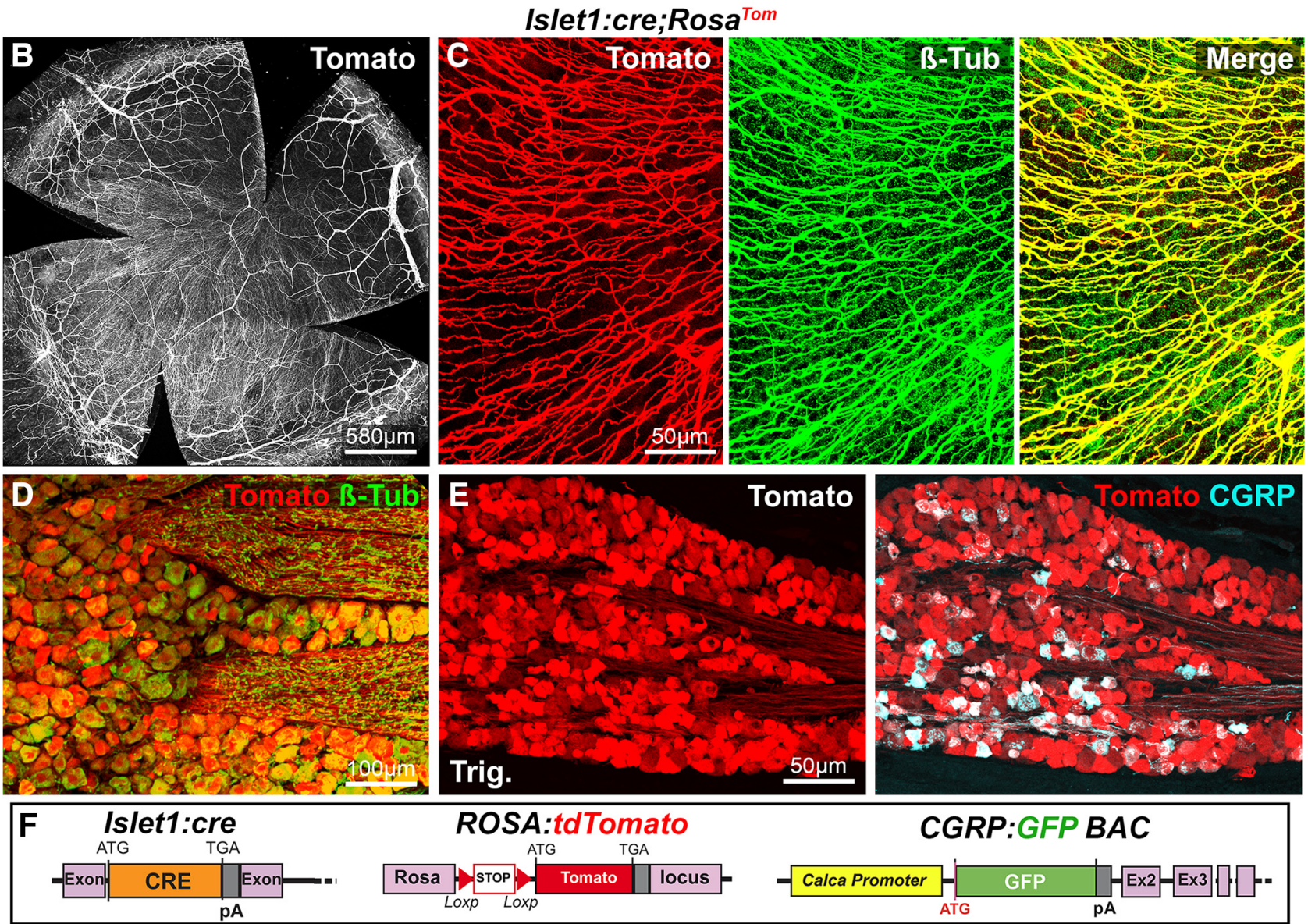

\section{Islet1:cre;Rosa ${ }^{\text {Tom; }}$ CGRP:GFP}
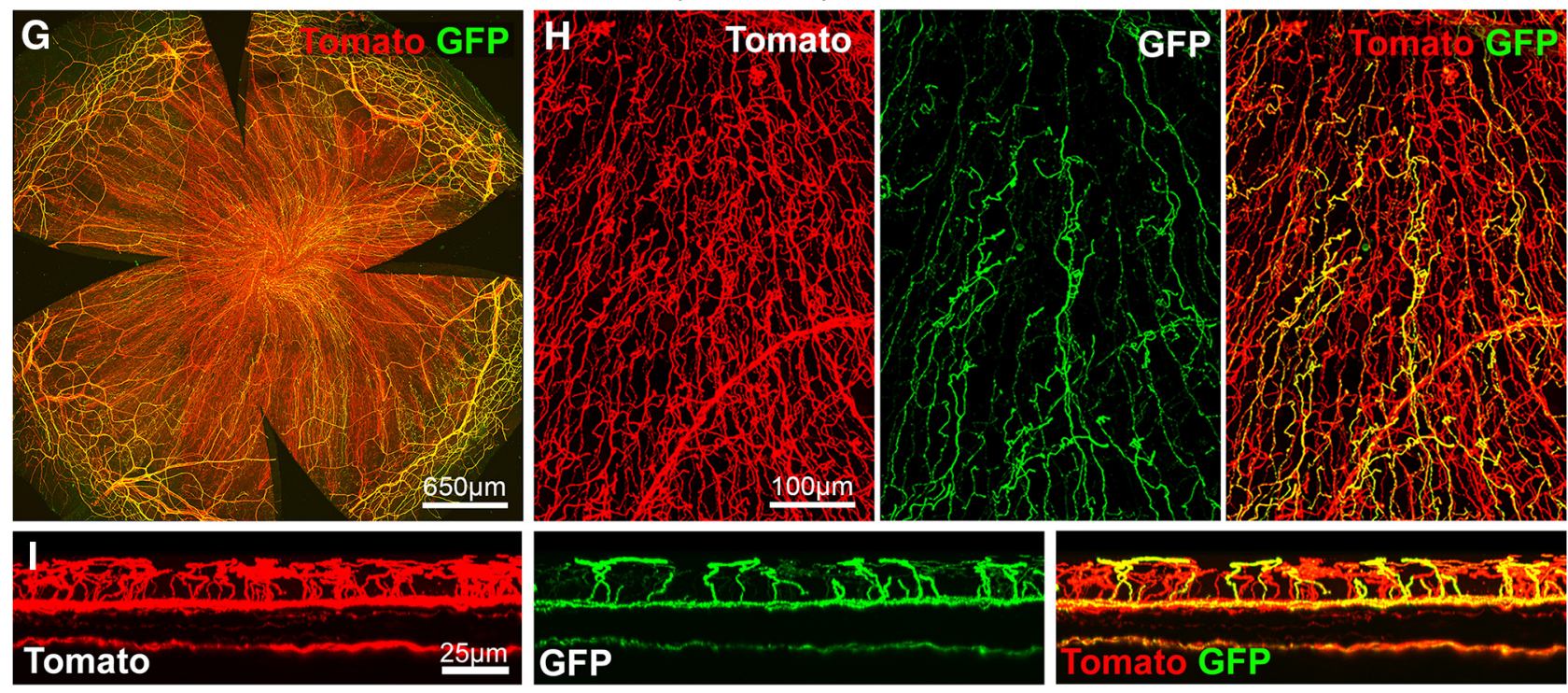

Figure 4. Visualization of corneal axons in Islet1:cre adult mice. $B, C, G, H$, Maximal intensity z-projection confocal stacks from adult whole-mount corneas. $A$, Description of the mouse lines. Rosa $^{\text {Tom }}$ (see Fig. 2). In $/$ slet1:cre knockin mice, the coding sequence of Cre was inserted in the is/1 gene by homologous recombination. $B, C$, In $/ s l e t 1$ :cre; Rosa ${ }^{\text {Tom }}$ mice, all corneal axons express Tomato (red). $\beta$ III-tubulin-immunoreactive axons (green) are also Tomato ${ }^{+}$(see merge). $\boldsymbol{D}, \boldsymbol{E}$, Confocal images of cryostat sections of trigeminal ganglia. $\boldsymbol{D}$, Colocalization of the GFP signal (green) and $\beta$ III-Tub immunoreactivity (red) in trigeminal neurons. E, All GGRP ${ }^{+}$neurons (cyan) coexpress Tomato. F, Description of the mouse lines. Islet1:cre (see above). (GRP:GFP (see Fig. 1). Rosa ${ }^{\text {Tom }}$

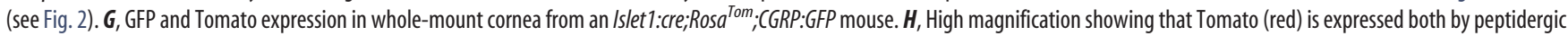
$\left(\mathrm{GFP}^{+}\right.$, green) and nonpeptidergic (GFP- ${ }^{-}$) axons. I, A reslice of the cornea (54- $\mu \mathrm{m}$-thick optical section) showing the location of the fluorescent axons. Yellow represents GFP ${ }^{+} /$Tomato $^{+}$ peptidergic nociceptor axons. Red represents nonpetidergic nociceptor axons. 


\begin{tabular}{|c|c|c|c|c|c|c|c|c|c|c|c|}
\hline \multirow[t]{3}{*}{$\mathbf{A}$} & \multirow{2}{*}{\multicolumn{3}{|c|}{ Ret:cre $_{\text {ATG }}^{E R}$ KI }} & \multirow{2}{*}{\multicolumn{3}{|c|}{ ROSA:tdTomato }} & \multicolumn{5}{|c|}{$T a u^{G F P}$} \\
\hline & & & & & & & & & & GA & \\
\hline & $=E x$ & CRE $^{\text {ERT2 }}$ & Ex2 $=$ & Rosa stop & Tomato & locus & Astop & $\Rightarrow$ & GFP & IRES & nls-Lacz \\
\hline
\end{tabular}
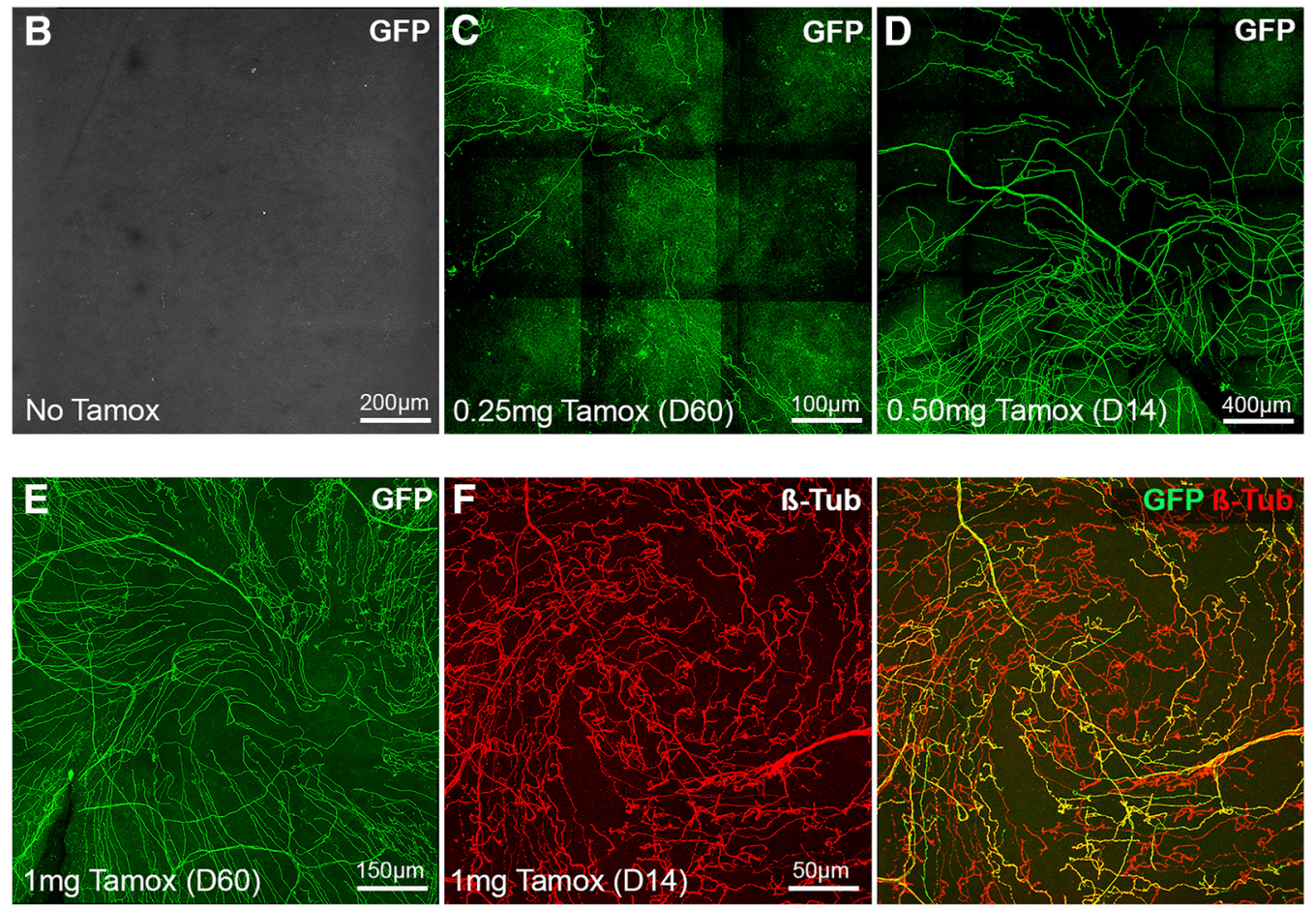

Ret:Cre;Rosa ${ }^{T o m}$
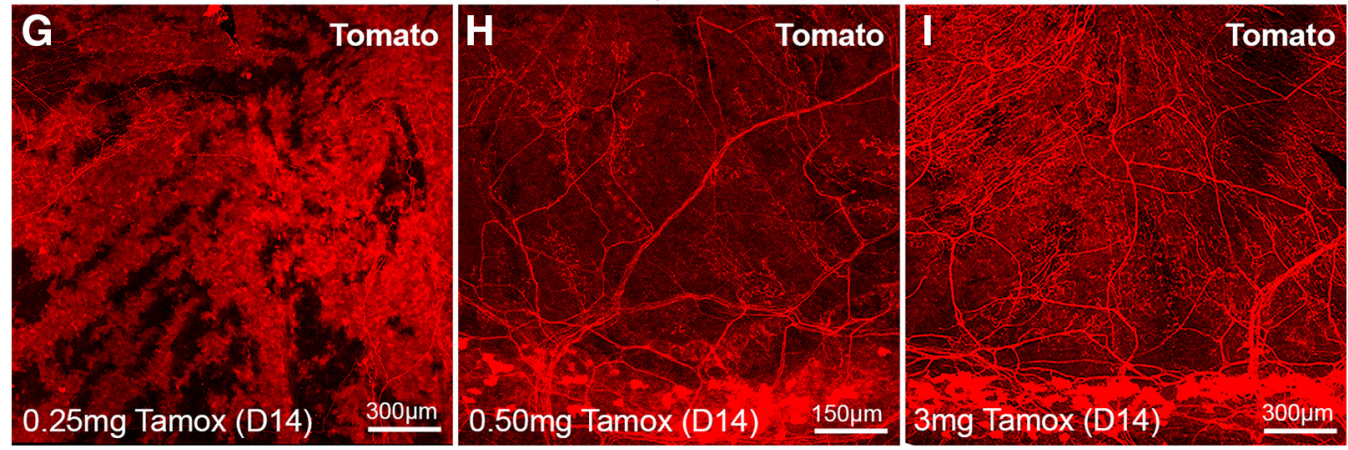

Figure 5. Visualization of corneal axons in Ret:cre ${ }^{\mathrm{ER}}$ adult mice. $\boldsymbol{B}-\boldsymbol{I}$, Maximal intensity z-projection confocal stacks from adult whole-mount corneas. $\boldsymbol{A}$, Description of the mouse lines Rosa ${ }^{\text {Tom }}$ and $T_{a u}{ }^{G F P}$ (see Fig. 2). In Ret:cre ${ }^{E R}$ knockin mice, the coding sequence of $c r e^{E R T 2}$ was inserted in the first exon of the Ret gene by homologous recombination. $\boldsymbol{B}$, In the absence of tamoxifen, no GFP signal is detected in the cornea of Ret:cre ${ }^{E R} ;$ Tau ${ }^{G F P}$ mice. C $-E$, The number of GFP ${ }^{+}$axons increases with the dose of tamoxifen injected $(0.25 \mathrm{mg}-1 \mathrm{mg})$. Corneas were collected $14 \mathrm{~d}(\mathrm{D} 14)$ or $60 \mathrm{~d}$ (D60) after injection. $\boldsymbol{F}$, Immunostaining for anti- $\beta$ III-tubulin shows that GFP is only expressed in a fraction of $\beta \| l l-T u b{ }^{+}$corneal axons. G-I, Corneas from Ret:cre ${ }^{E R} ;$ Rosa ${ }^{T o m}$ mice injected with increasing doses of tamoxifen injected $(0.25-3 \mathrm{mg})$. At the lowest dose $(\boldsymbol{G})$, many Tomato ${ }^{+}$corneal cells are seen and mask Tomato ${ }^{+}$axons. $\boldsymbol{H}, \boldsymbol{I}$, At higher doses, highly fluorescent cells are seen in the limbal region, and more Tomato ${ }^{+}$axons are observed.

En1:Cre line

We next continued to test other Cre lines that, unlike the Wnt1: cre and Tag-1:cre lines, could drive transgene expression in a small subset of trigeminal neurons and therefore result in a sparse labeling of corneal axons.

The engrailed-1 (En1) transcription factor controls the development of some neural crest cell derivatives, including the trigeminal placode (Zhong et al., 2010; Deckelbaum et al., 2012). Therefore, we crossed, En1:cre mice (Kimmel et al., 2000) with $\operatorname{Rosa}^{\text {Tom }}(n=2)$ and Tau ${ }^{G F P}(n=3)$ lines (Fig. $\left.3 H\right)$. The results were similar to the two other Cre lines: strong expression of Tomato in cornea cells (Fig. 3I) and strong GFP expression in corneal nerves (Fig. $3 J, K$ ). In the trigeminal ganglia, almost all neurons were $\mathrm{GFP}^{+}$(Fig. $3 L$ ), as shown by $\beta$ III-tubulin immunostaining $(n=3)$, and they comprised nonpeptidergic (binding IB4; Fig. $3 L)$ and peptidergic $\left(\mathrm{CGRP}^{+}\right.$; Fig. $\left.3 M\right)$ C-fibers.

\section{Islet1 line}

Next, we tested the Islet1:cre line (Fig. $4 A$ ) as in mice; this transcription factor controls the formation of the trigeminal ganglia and autonomic ganglia (Sun et al., 2008; Coppola et al., 2010). Islet1 appears to be expressed most, if not all, trigeminal neurons (Sun et al., 2008; Coppola et al., 2010; Meng et al., 2011). Interestingly, all corneal nerves were found to highly express Tomato in Islet1:cre;Rosa ${ }^{\text {Tom }}$ corneas (Fig. $4 B ; n>10$ ) as supported by anti- $\beta$ III-tubulin immunostaining (Fig. $4 C$ ). This was also the 
case in the trigeminal ganglia where all CGRP ${ }^{+}$and $\beta$ III-tubulin neurons appeared to express Tomato $(n=3)$ (Fig. $4 D, E)$. Therefore, this genetic combination drives the expression of a red fluorescent protein in most, if not all, corneal nerves, suggesting that the corresponding neurons either derive from Islet $1^{+}$neural crest and placode progenitors or express islet 1 when their fate is established. This observation led us to combine the CGRP:GFP and Islet1:cre;Rosa ${ }^{\text {Tom }}$ lines (Fig. $4 F$ ). Strikingly, in the compound line, two populations of corneal axons, coexpressing GFP and Tomato or only expressing Tomato, could be visualized by confocal microscopy $(n=5)$ (Fig. $4 H, I)$.

Ret:cre ${ }^{E R}$ line

Although all the above lines will be extremely useful to study corneal innervation, they do not reveal the morphology and branching pattern of individual trigeminal axons. To address this problem, we tested the Ret:cre ${ }^{E R}$ knockin line (Luo et al., 2009). The Ret receptor tyrosine kinase controls the development of mechanoreceptor neurons (Luo et al., 2009) and is broadly expressed in trigeminal neurons (Coppola et al., 2010), and Ret neurons can be divided into two main groups (Luo et al., 2009). Most Ret ${ }^{+}$neurons are peptidergic nociceptors $\left(\mathrm{CGRP}^{+}\right)$, and a few parts are nonpeptidergic nociceptors. Among this two populations of Ret ${ }^{+}$neurons, some have large-diameter soma and exhibit features of mechanosensory neurons.

As tamoxifen injection is needed to activate Cre-dependent recombination, it should, in principle, allow temporal control of Cre recombinase activity and modulation of the number of trigeminal neurons activating Cre, by adjusting the dose of tamoxifen injected to the mice.

To test this hypothesis, Ret:cre ${ }^{E R}$ mice were first crossed to $T a u^{G F P}$ mice (Fig. 5A). In absence of tamoxifen, corneas did not contain any fluorescent axons (Fig. $5 B ; n>10$ ). Mice were next injected once with increasing doses of tamoxifen and corneas collected 14 or $60 \mathrm{~d}$ later. At the lowest dose $(0.25 \mathrm{mg} ; n>10)$, a sparse labeling was obtained with only a few $\mathrm{GFP}^{+}$axons seen in the cornea (Fig. $5 C$ ). At an intermediate dose ( $0.5 \mathrm{mg} ; n=5)$, the density of $\mathrm{GFP}^{+}$axons was significantly increased (Fig. 5D) but did not fill homogeneously the cornea. When the tamoxifen dose was doubled ( $1 \mathrm{mg} ; n>10$ ), the density of fluorescent axons was further increased but still only represented a fraction of the corneal nerves as demonstrated by $\beta$ III-tubulin immunostaining (Fig. 5E,F). Next, we analyzed Ret:cre ${ }^{E R} ; \operatorname{Rosa}^{T o m}$ doubletransgenic mice. At the lowest tamoxifen dose, the cornea was almost completely filled with Tomato-positive cells, but a few axons could be imaged despite the high Tomato expression in corneal cells (Fig. $5 G ; n=5$ ). By contrast, at the higher doses, Tomato $^{+}$axons were readily seen in addition to corneal cells (Fig. $5 H, I ; n>10$ ). We next attempted to combine the three lines to determine whether combinatorial expression of GFP and Tomato could be achieved when the two reporter lines were simultaneously intercrossed with the Ret:cre ${ }^{E R}$ line. We also used a higher dose of tamoxifen $(3 \mathrm{mg})$ and also immunostained the corneas of Ret:cre ${ }^{E R} ; \operatorname{Rosa}^{\text {Tom }} ; \mathrm{Tau}^{G F P}$ mice with anti- $\beta$ III tubulin $(n=3)$.

This strategy resulted in the multicolor labeling of corneal innervation, with a majority of axons expressing both fluorescent proteins (and therefore appearing yellow) and a lower number of axons expressing a single protein, either Tomato or GFP (Fig. $6 A, B)$. This could be partially due to the weaker intensity of the GFP signal. Tomato ${ }^{+}$and $\mathrm{GFP}^{+}$axons (alone or in combination) represented $59 \%$ of $\beta I I I$ tubulin ${ }^{+}$axons $(n=3)$. A similar result was obtained with Ret:cre ${ }^{E R} ; \operatorname{Rosa}^{T o m} ; T a u^{S y n-F P}$ mice $(n=$ 3) (Fig. 6C,D).

We next crossed the Ret:cre ${ }^{E R} ; R_{0 s} a^{\text {Tom }}$ and the CGRP:GFP lines. The resulting Ret:cre ${ }^{E R} ; \operatorname{Rosa}^{\text {Tom }} ;$ CGRP:GFP mice were first injected with a low dose of tamoxifen $(n=3)$. The trajectories of individual Tomato ${ }^{+}$axons within larger $\mathrm{GFP}^{+}$axonal trunks could be followed (Fig. $6 F$ ), and their terminal arbors as they stem from these large trunks were also visible (Fig. $6 G$ ). At a high dose of tamoxifen $(n=3)$, GFP and Tomato were expressed in a combinatorial manner in Ret:cre ${ }^{E R} ; \operatorname{Rosa}^{\text {Tom }}$;CGRP:GFP corneas, with only a small subset of axons expressing only one protein (Fig. 6H). Administration of tamoxifen (3 mg) to the Ret:cre ${ }^{E R}$; Rosa ${ }^{\text {Tom }}$;CGRP:GFP reporter adult mice led to expression of Tomato (D14) in large soma NF200 ${ }^{+}$neurons, $\mathrm{CGRP}^{+}$neurons, and IB4 ${ }^{+}$neurons $(n=5)$.

We also used the Ret:cre ${ }^{E R}$ mice crossed to Tau ${ }^{G F P}$ mice injected with a low dose of tamoxifen $(0.25 \mathrm{mg})$ to visualize the morphology and branching pattern of individual corneal axons. Corneal axons of 10 corneas (143 axons in total) were traced using the Imaris Neurofilament tool software on confocal images at a $40 \times$ magnification (Fig. $7 A, B$ ). This showed that individual axons extended relatively straight in a centripetal manner and only bear a few side branches laterally. Reconstructions of superficial nerve terminals in the mouse corneal epithelium led us to identify three types of nerve terminals, as described previously (Ivanusic et al., 2013; Alamri et al., 2015, 2018): simple (Fig. $7 E, G$ ), 33 multiple (Fig. $7 C, D, H$ ), and 34 complex (Fig. $7 F, I$ ). Simple terminals (Fig. $7 E, G$ ) do not branch after leaving the sub-basal nerves and end with a single, bulbar swelling at the superficial surface of the epithelium. These were more frequent in the center of the cornea than in the periphery. Multiple terminals (Fig. $7 C, D, H$ ) branch within the epithelium into a small number (usually 3 or 4) of horizontal fibers that run parallel to the surface. Each of these branches end in a single bulbar swelling similar to those associated with simple terminals. These ramifying terminals were most obvious in the peripheral cornea. The axons forming the complex terminals (Fig. 7F,I) form a cluster of highly branched fibers that have many branches. These complex terminals have multiple bulbar endings, and many of these bulbar endings are larger than those associated with the simple and ramifying terminals. Complex terminals were found in both the central and peripheral parts of the cornea. Although a recent study conducted in guinea pig (Alamri et al., 2015) reported morphological differences between localization of axonal endings in terms of basal versus apical epithelium, we were unable to define nerves endings on the basis of their localization in mice.

\section{Other mouse lines tested}

Previous studies have identified other transgenic lines in which fluorescent proteins selectively label subsets of axons innervating the hairy skin (Fig. 8; for line descriptions, see Materials and Methods). For instance, GFP is expressed by lanceolate A $\delta$ LTMRs in TrkB:TauGFP mice (Li et al., 2011; Rutlin et al., 2014) and $\mathrm{A} \beta$ rapidly adapting (RA)-LTMRs in Split:cre mice (Rutlin et al., 2014). A $\beta$ RA-LTMRs also express tdTomato in Npy2r: tdTomato mice (Gong et al., 2003; Li et al., 2011). These two types of LTMRs are absent from the cornea; and accordingly, no fluorescent axons were detectable in corneas from mice belonging to these three lines (Fig. $8 A-C ; n=2$ for each). Scattered GFPpositive cells, possibly resident macrophages (Brissette-Storkus et al., 2002), were observed in TrkB:TauGFP corneas. Likewise, no GFP-fluorescent nerves were found in the corneas of Mrgprd: GFP mice (Fig. $8 D ; n=2$ ) in which GFP is exclusively expressed 

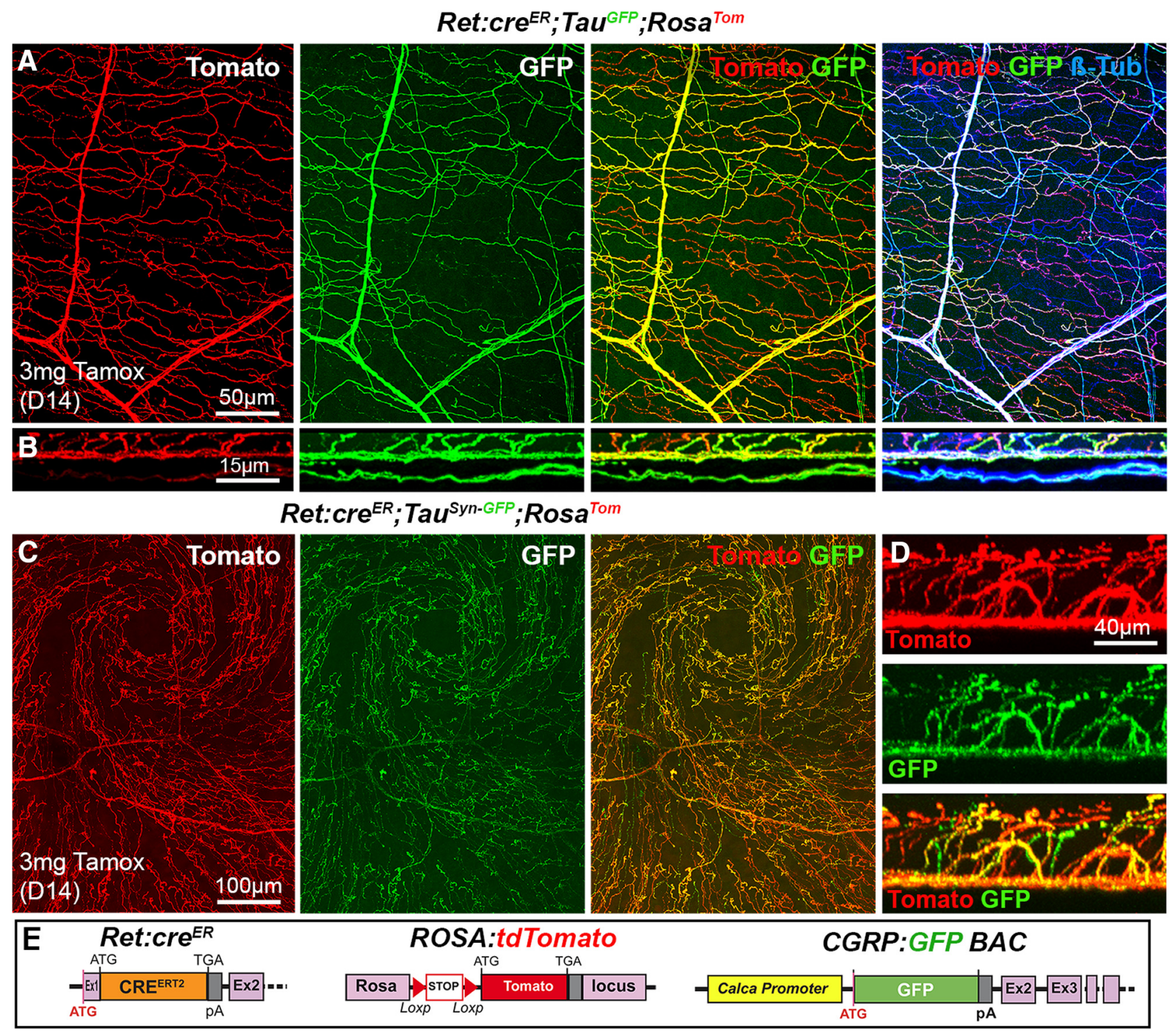

\section{Ret:Cre ${ }^{E R} ;$ Rosa $^{T o m} ; C G R P: G F P$}

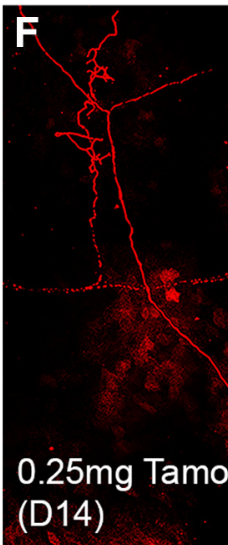

\begin{tabular}{c} 
Tomato \\
\\
$50 \mu \mathrm{m}$ \\
\hline
\end{tabular}
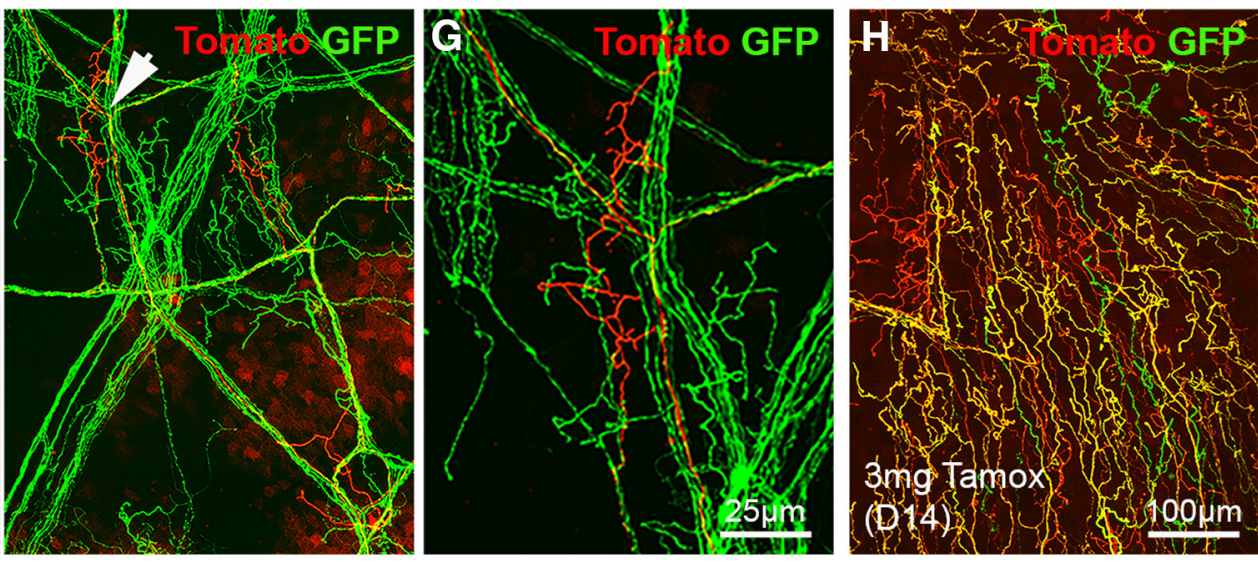

Figure 6. Analysis of corneal nerves in Ret:cre ${ }^{\mathrm{ER}}$ compound mice. All images (except $\boldsymbol{B}$ and $\boldsymbol{D}$ ) are maximal intensity z-projection confocal stacks from adult whole-mount corneas. $\boldsymbol{A}$, Cornea from a Ret:cre ${ }^{E R} ; T_{a}{ }^{G F P} ;$ Rosa ${ }^{\text {Tom }}$ mouse immunolabeled for $\beta$ III-tubulin. Some $\beta$ III-Tub ${ }^{+}$axons (blue) also coexpress GFP and Tomato (and appear white). 0 ther axons that only express GFP (right, green or cyan) or only Tomato (right, red or magenta). $\boldsymbol{B}$, A reslice of the cornea (54- $\mu \mathrm{m}$-thick optical section) illustrating the distribution of the fluorescent axons in the stroma and epithelium. $\boldsymbol{C}$, Image

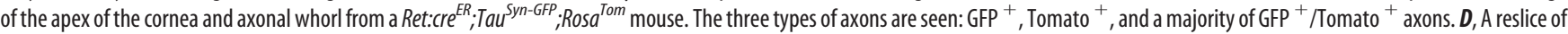
the cornea (54- $\mu \mathrm{m}$-thick optical section). E, Description of the mouse lines. (GRP:GFP (see Fig. 1). Rosa ${ }^{T o m}$ (see Fig. 2). Ret:cre ${ }^{E R}$ (see Fig. 5). $\boldsymbol{F}, \boldsymbol{G}$, With a low dose of tamoxifen (0.25 mg), only a few Tomato $^{+}$axons and do not always overlap with GFP ${ }^{+}$nociceptive axons. Middle, Arrowhead indicates the area seen on the high-magnification image of a single tomato ${ }^{+}$terminal arbor (right). $\boldsymbol{H}$, With a high dose of tamoxifen, most axons coexpress GFP and Tomato, but a few only express a single fluorescent protein. 

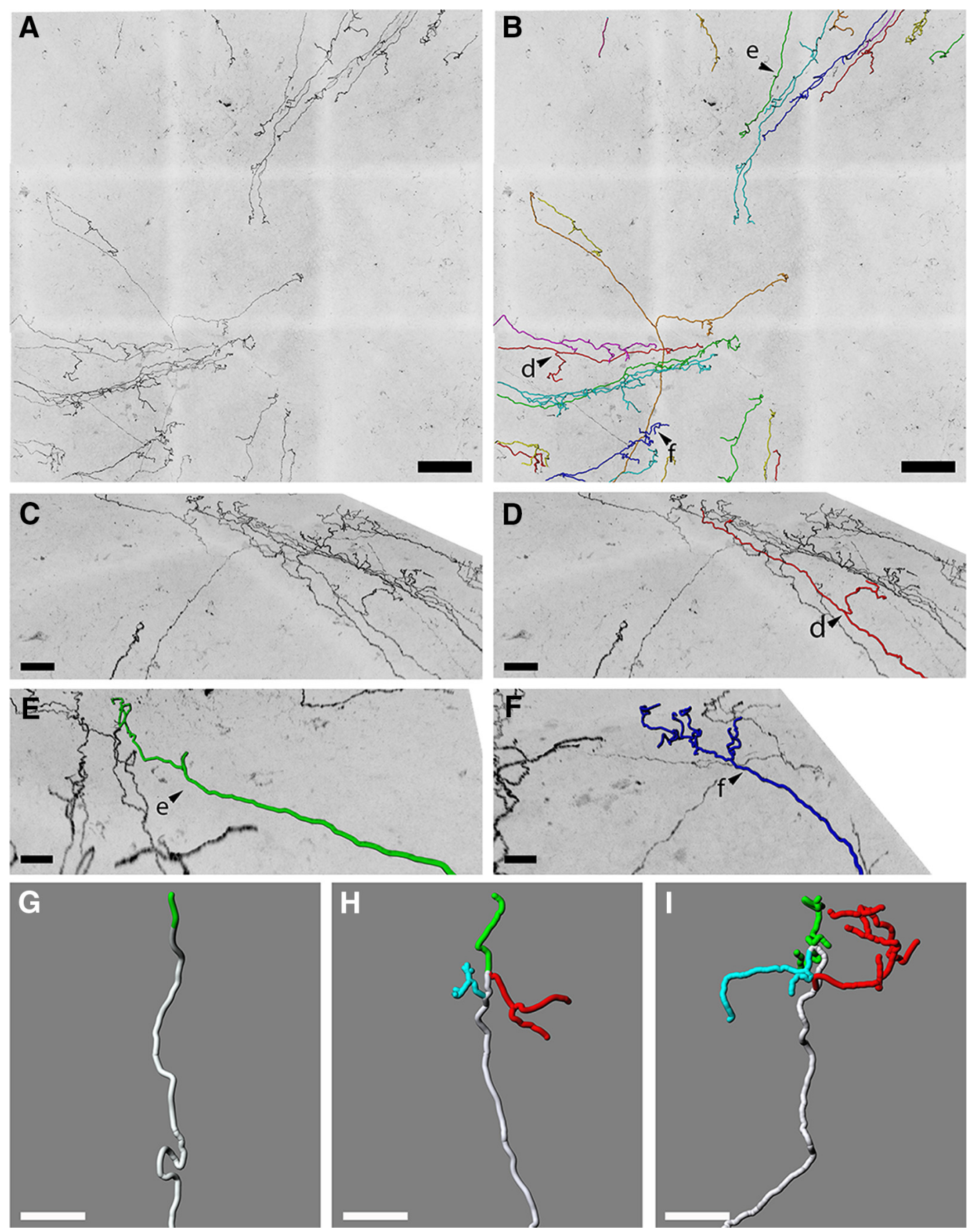

Figure 7. Heterogeneous terminal arborization of corneal axons. $A$, Maximal intensity z-projection confocal stacks from adult Ret:cre ${ }^{E R}$; Tau ${ }^{G F P}$ whole-mount corneas injected with a low dose of tamoxifen $(0.25 \mathrm{mg})$. $\boldsymbol{B}$, Axons from $\boldsymbol{A}$ were analyzed with Imaris software using the Filament Tracer module. Arrowheads $\mathrm{d}$, e and f indicate axons seen at higher magnification in panels $\boldsymbol{D}, \boldsymbol{E}$ and $\boldsymbol{F}$. $\boldsymbol{C}$, High-magnification image showing single axons in a sagittal view. $\boldsymbol{D}$, Single axon tracing showing ramifying nerve terminal. $\boldsymbol{E}$, Single axon tracing showing simple nerve terminal. $\boldsymbol{F}$, Single axon tracing showing complex nerve terminal. $\mathbf{G}-\boldsymbol{I}$, Reconstructions of superficial nerve terminals in the mouse corneal epithelium showing examples of simple $(\boldsymbol{G})$, ramifying $(\boldsymbol{H})$, and complex $(\boldsymbol{I})$ nerve terminals based on 143 axons.

in nonpeptidergic neurons that innervate the epidermis (Zylka et al., 2005). More surprisingly, we could not observe fluorescent axons, in corneas from VGluT3:GFP BAC transgenics (Fig. 8E), although in the epidermis $(n=2)$, GFP was shown to be expressed in nonpeptidergic LTMR-C fibers (Seal et al., 2009), which exist in the cornea (Müller et al., 2003; Alamri et al., 2015).

It was previously shown that YFP is expressed in a large fraction of corneal nerves in Thyl:YFP mice (Yu and Rosenblatt, 2007; Namavari et al., 2011; Taylor-Clark et al., 2015). Interestingly, lines expressing a Brainbow cassette under the Thy1 promoter were generated (Livet et al., 2007), suggesting that multicolor labeling of corneal axons could be achieved using the Brainbow strategy. Brainbow is a transgenic system based on Crelox recombination for stochastic expression of multiple genes coding spectrally distinct fluorescent proteins. We used the Thy1Brainbow 1.0 line in which the red fluorescent protein tdimer2 (RFP) is expressed by default (Livet et al., 2007), whereas either the blue fluorescent protein Cerulean (CFP) or the yellow fluorescent protein (YFP) are expressed upon Cre-driven recombination. Accordingly, $\mathrm{RFP}^{+}$axons could be observed in the cornea of Thy1.Brainbow1.0 mice (data not shown). To trigger the recombination of the Brainbow cassette in corneal nerves, we 
TrkB:TauGFP

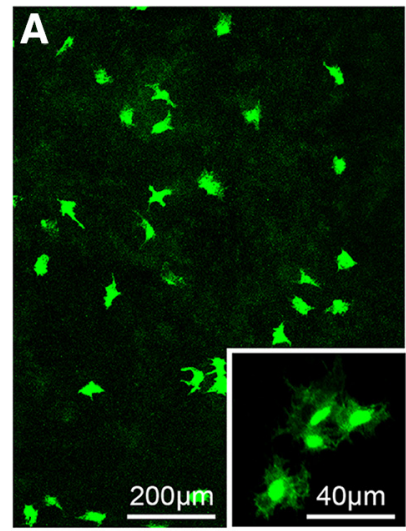

Vglut3:GFP

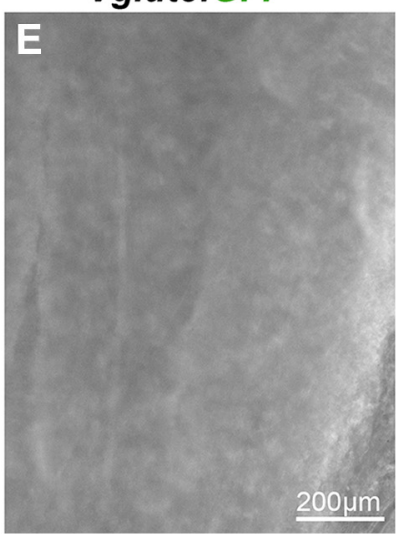

Split:cre:GFP

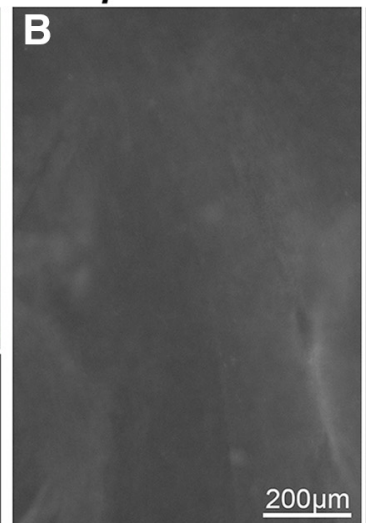

Mrgprd:GFP

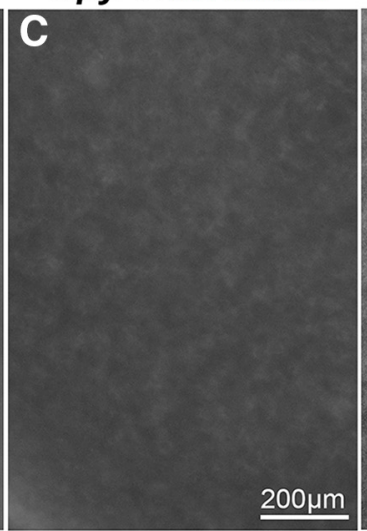

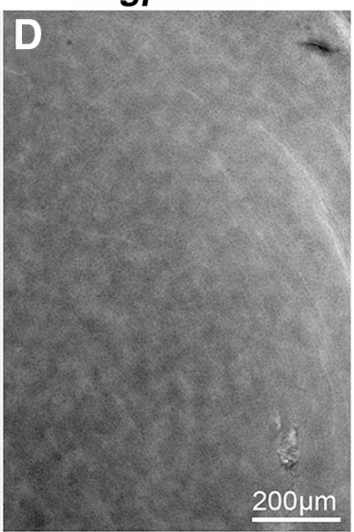

\section{CAG:Cre ${ }^{E R T 2}$;Thy1-Brainbow1.0}
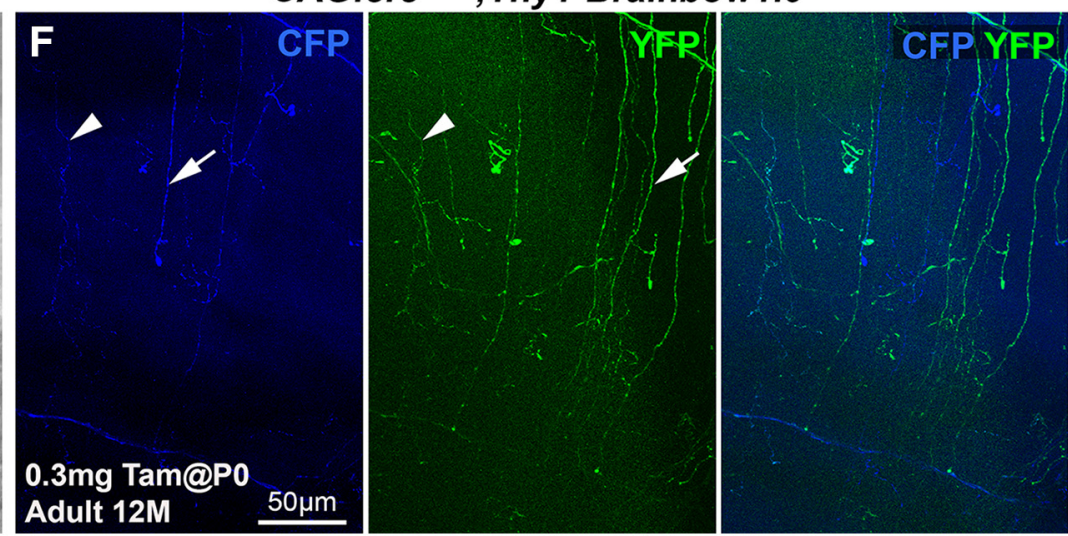

Figure 8. Other transgenic lines tested. Maximal intensity z-projection confocal stacks $(\boldsymbol{A}, \boldsymbol{F})$ or epifluorescence images ( $\boldsymbol{B}-\boldsymbol{E})$ from adult whole-mount corneas. $\boldsymbol{A}-\boldsymbol{E}$, No fluorescent corneal axons were detected in TrkB:Tau ${ }^{\text {GFP }}$, Split:cre:GFP, Npy2r:tdTomato, Mrgprd:GFP, and Vglut3:GFP mice. Note the presence of scattered GFP ${ }^{+}$cells in TrkB:Tau ${ }^{\text {GFP }}$ line. F, Cornea from a 12-month-old CAG:Cre ${ }^{\text {ERT2}}$;Thy1-Brainbow1.0 mouse injected with $0.3 \mathrm{mg}$ of tamoxifen at P0. A few CFP ${ }^{+}$axons (blue) and YFP ${ }^{+}$(green) axons are seen. Left, Middle, Arrowhead indicates a CFP ${ }^{+} /$YFP $^{+}$ double-labeled axon. Arrow indicates axons that are either YFP ${ }^{+}$or CFP ${ }^{+}$.

used the CAG:cre ${ }^{E R T 2}$ line (Guo et al., 2002) that expresses almost ubiquitously a tamoxifen-inducible Cre recombinase. As expected, upon tamoxifen injection (see Materials and Methods), we could observe axons expressing YFP, CFP, or both (Fig. 8F), but fluorescence intensity was very low and we could not detect any RFP signal, suggesting that all cassettes were recombined with the tested protocol $(n=3)$. Therefore, this line was not used further.

\section{Analysis of corneal nerve reorganization during aging}

Our next objective was to use transgenic lines to study the remodeling of corneal nerves during aging as little information on this process is currently available. We focused on the CGRP:GFP line as GFP expression is very robust in a well-characterized population of corneal axons (peptidergic nociceptors). In CGRP:GFP newborns (Fig. 9A; $n=5$ ), $\mathrm{GFP}^{+}$axons already formed a dense ring-like network at the periphery of the cornea in the limbal region. $\mathrm{GFP}^{+}$axons were also found extending toward the center of the cornea, but they expressed lower level of GFP (see also Fig. $1 H)$. By P10, GFP ${ }^{+}$axons covered completely the cornea and terminal intraepithelial branches were numerous, but there was not yet any obvious polarization or corneal axons (Fig. $9 B ; n=8$ ). By $\mathrm{P} 21$, the typical axonal leashes started to form and to acquire their centripetal orientation (Fig. 9C; $n=5$ ). This remodeling was more advanced at 1 month with also the first evidence for the development of an axonal spiral or whorl-like vortex at the center of the cornea (Fig. 9D; $n=5$ ). In 4-month-old CGRP:GFP mice, the corneal innervation pattern of $\mathrm{GFP}^{+}$axons was fully mature with a clear centripetal polarity and pronounced central vortex (Fig. $9 E ; n=5)$. Interestingly, between 6 and 9 month of age $(n=$ 10 ), evidence for a deterioration of the corneal innervation were detected primarily affecting axons located at the cornea apex (Fig. $9 F, G)$. The structure of the vortex was often disorganized with either axons lacking a spiral organization or with a disappearance of $\mathrm{GFP}^{+}$axons in the central region. This was accompanied at older ages $(12-18$ months; $n=6$ and $n=6$ ) by a reduction in the density of CGRP ${ }^{+}$axonal leashes followed by the reappearance of disoriented axonal branches seen at immature stages (Fig. 9H,I).

Corneal CGRP ${ }^{+}$innervation density decreases significantly in the center and in the periphery with the age of the mice at $4(n=$ $5), 12(n=5)$, and $18(n=5)$ months of age. Density in the center of the cornea was measured at $214,019 \pm 10,107$ pixels at 4 months and then decreased to $148,333 \pm 25,482$ pixels at 12 months $(p=0.04)$ and to $77,068 \pm 11,268$ pixels at 18 months $(p=0.006)$. Density in the periphery of the cornea was measured at $173,045 \pm 12,823$ pixels at 4 months and then decreased to $80,500 \pm 8045$ pixels at 12 months $(p=0.007)$ and to $55,807 \pm$ 7830 pixels at 18 months $(p=0.03)$.

\section{Neuropilin-1 control the postnatal development of the corneal innervation}

The molecular factors controlling the development and maintenance of corneal innervation are still largely unknown. Sema3A and Sema3F and their respective receptors, neuropilin-1 and 

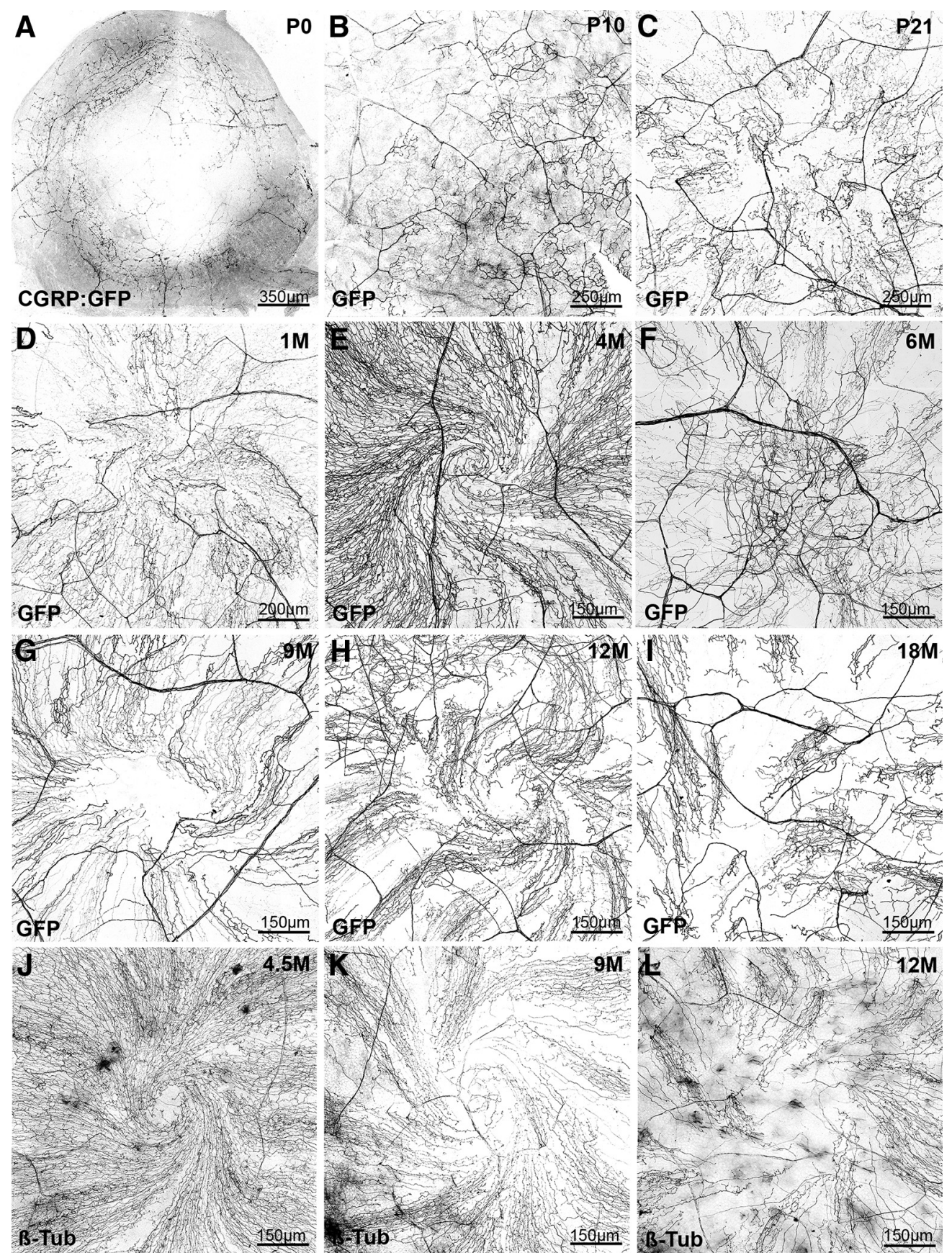

Figure 9. Age-dependent evolution of the corneal innervation in CGRP:GFP mice. All images are maximal intensityz-projection confocal stacks from whole-mount corneas. A negative image was generated as fluorescent axons are more visible in black on a white background. $\boldsymbol{A}-\boldsymbol{D}$, Developmental time course of corneal innervation in (GRP:GFP mice during the first postnatal month. The progressive centripetal extension and polarization of the axonal leashes. $\boldsymbol{E}$, At 4 months, the axonal vortex at the center of the cornea is well formed (compare with $\boldsymbol{D})$. $\boldsymbol{F}-\boldsymbol{H}$, Abnormal pattern of innervation in the center of the cornea, frequently observed from 6 to 9 months. $\boldsymbol{H}$, The lower density of GFP ${ }^{+}$axons compared with $\boldsymbol{E}$. $\boldsymbol{I}$, cornea from an 18-month-old GRP:GFP mouse. The axonal whorl is absent, axonal leashes are not seen in the center of the cornea, and polarity is perturbed. Larger areas do not contain GFP ${ }^{+}$axons. $J-L$, WT corneas immunolabeled with anti-tubulin. The progressive thinning of corneal innervation is also seen from 9 months, as well as the disorganization of axonal leashes in a 1-year-old mouse.

neuropilin-2, control the initial branching of trigeminal axons on the embryonic cornea (McKenna et al., 2012). The embryonic or perinatal lethality of most mice deficient in axon guidance molecules has hampered the analysis of the molecular mechanisms involved in the postnatal development of corneal axons. Interestingly, our genetic screen uncovered several lines expressing Cre recombinase in ophthalmic trigeminal axons. Therefore, we next attempted to use these lines to study the role of axon guidance molecules in the development of cornea innervation.
We first focused on Neuropilin-1 (Npn1), which is the binding component of the receptor complex for Sema3A, a secreted semaphorin expressed in the developing lens and cornea (Lwigale and Bronner-Fraser, 2007; Ko et al., 2010). There is a severe defasciculation of embryonic trigeminal axons in a mouse ENU mutant expressing a mutated Sema 3 unable to bind Neuropilin-1 (Merte et al., 2010) as well as in Sema3A KO embryos (Ulupinar et al., 1999). To inactivate neuropilin-1 in trigeminal axons, we crossed Npn1 ${ }^{\text {lox }}$ conditional KOs (Gu et al., 2003) to TAG-1:cre 

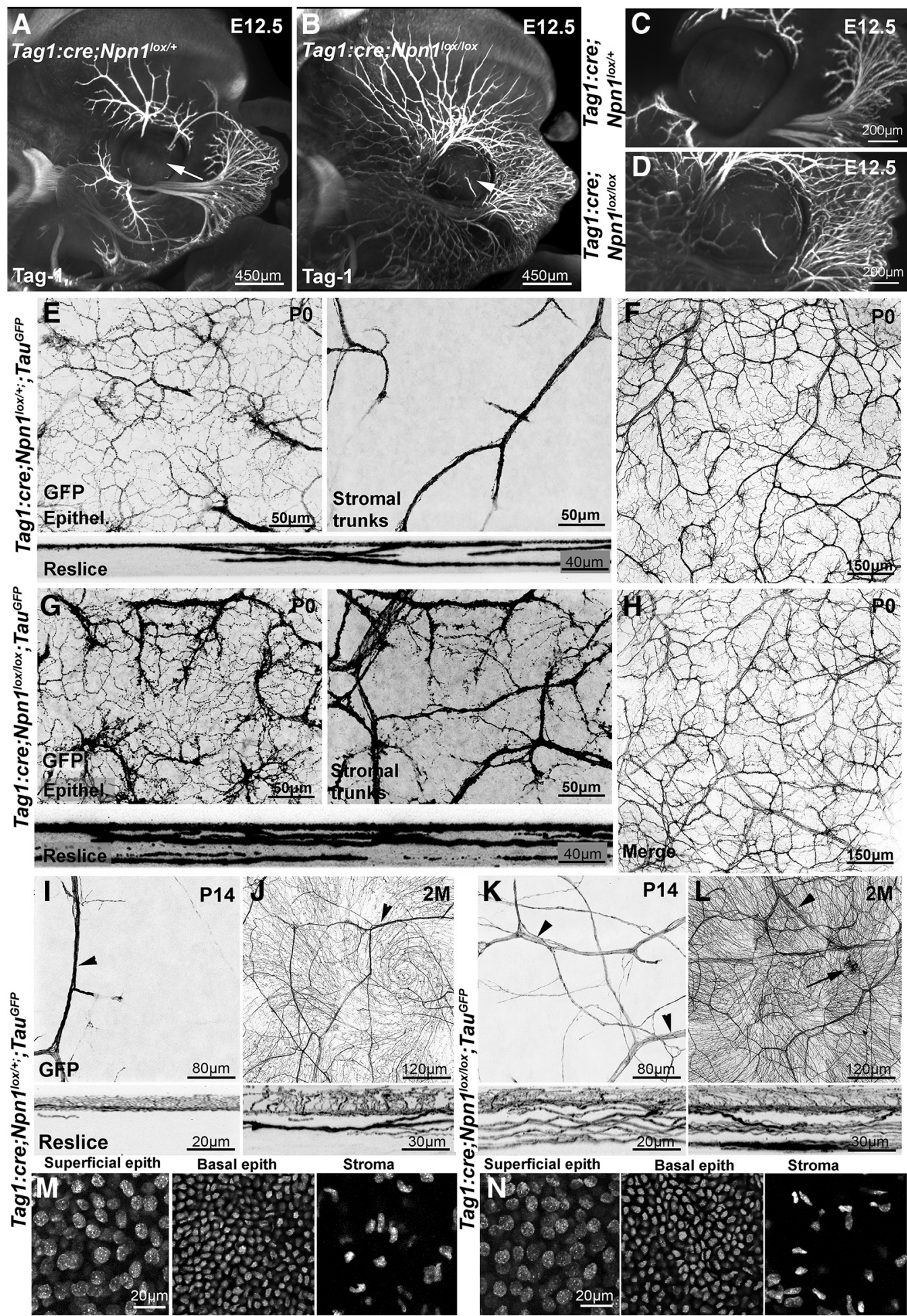

Figure 10. Neuropilin-1 controls the development of corneal innervation. $\boldsymbol{A}-\boldsymbol{D}$, Light sheet microscopy $3 \mathrm{D}$ images of E12.5 TAG-1:cre; Npn $7^{\text {lox/+ }}(\boldsymbol{A}, \boldsymbol{C})$ and TAG-1:cre; Npn $7^{\text {lox/lox }}(\boldsymbol{B}, \boldsymbol{D})$ embryos, immunolabeled with anti-Tag-1 antibodies and cleared with 3DISCO. Tag- ${ }^{+}$sensory axons innervating the face are more numerous and highly defasciculated in TAG-1:cre;Npn ${ }^{10 x / 10 x}$ embryo.

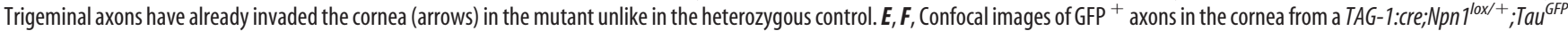
newborn mouse at the level of the epithelium ( $\boldsymbol{E}$; Epithel.) or the stroma $\left(\boldsymbol{E}\right.$; stromal trunks) and the whole cornea $(\boldsymbol{F})$. The GFP ${ }^{+}$axons already form a dense network in the sub-basal plexus. A few

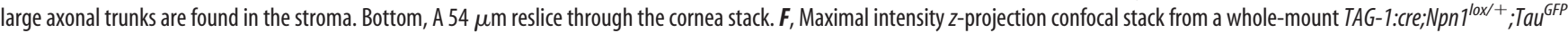
cornea. $\mathbf{G}, \boldsymbol{H}$, Confocal images of GFP ${ }^{+}$axons in the cornea from a TAG-1:Cre; Npn $7^{\text {Iox/lox; }}$; Ta $^{G F P}$ newborn mouse. The density of GFP ${ }^{+}$axons and branches is strongly increased in the sub-basal plexus $(\boldsymbol{G}$, left) compared with heterozygous controls. The stroma also contains a much higher number of large axonal trunks (right). Bottom, A54 $\mu$ m reslice through the cornea stack. $\boldsymbol{H}$, Maximal intensity z-projection confocal stack from a whole-mount TAG-1:cre; Npn ${ }^{10 x / 10 x}$; $\mathrm{Tau}^{G F P}$ cornea. $I-L$, The density of GFP ${ }^{+}$axonal branches and large nerve trunks (arrowheads) in the epithelium and stroma

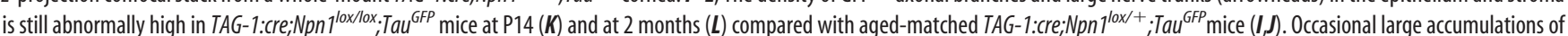

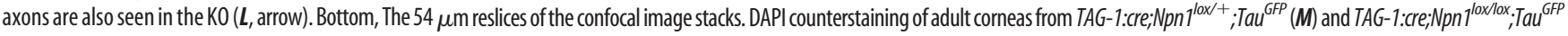
(M) mice. Density of superficial epithelial cells, basal epithelial cells, and keratocytes in the stroma is similar in mutant and control mice. 
mice. To validate this strategy, we first studied trigeminal projections in E12.5 TAG-1:cre;Npn1 ${ }^{\text {lox }}$ embryos, as severe sensory nerve branching defects were previously observed at this age in $N p n 1^{-/-}$null embryos (Kitsukawa et al., 1997). The ophthalmic branches of the trigeminal nerve were visualized using antiTAG-1 immunostaining, 3DISCO tissue clearing, and 3D light sheet microscopy (Belle et al., 2014). We found that ophthalmic axons were highly defasciculated in TAG-1:cre; Npn1 $1^{\text {lox/lox }} \mathrm{em}-$ bryos compared with TAG-1:cre;Npn1 $1^{\text {lox/+ }}$ controls (Fig. 10A,B; $n=3$ for each genotype), and the total length of the ophthalmic V1 branch (main trunk and all branches of the superior ophthalmic division of the trigeminal nerve surrounding the eye) was strongly increased ( $18 \pm 1.5 \mathrm{~mm}$ in mutant compared with $4.3 \pm$ $0.24 \mathrm{~mm}$ in control; $p=0.003$ ). At this age, the cornea of the TAG-1:cre; Npn 1 ${ }^{\text {lox/lox }}$ embryos was prematurely innervated (Fig. $10 C, D)$ containing $1.7 \pm 0.11 \mathrm{~mm}$ of Tag- $1^{+}$axons compared with $0.12 \pm 0.03 \mathrm{~mm}$ in corneas from controls $(p=0.001)$. A premature innervation of the cornea has been previously reported in embryo from a Neuropilin-1 mutant line in which this receptor is unable to bind its ligand Sema3A (McKenna et al., 2012). These results show that, in this line, Neuropilin-1 was inactivated in trigeminal projections to the cornea. In contrast to $N p n 1^{-/-}$mutants, TAG-1:cre;Npn1 $1^{\text {lox/lox }}$ mice were viable and survive to adulthood. To visualize trigeminal axons postnatally in conditional KOs, we crossed them to Tau ${ }^{G F P}$ mice.

At birth, abnormal development of corneal innervation was observed in TAG-1:cre; Npn1 $1^{\text {lox/lox }}$ on confocal images of wholemount corneas (Fig. 10E-H). In comparison with TAG-1:cre; $N p n 1^{l o x /+}$ controls $(n=3)$, the density and branching of GFP ${ }^{+}$ axons were strongly increased in TAG-1:cre; $N p n 1^{\text {lox/lox }}$ newborn mice $(n=3)$, both in the subepithelial plexus $(98,333 \pm 12,583$ pixels in mutant vs $34667 \pm 4509$ pixels in controls; $p=0.009$ ) and in the stroma $(88,667 \pm 10,969$ pixels in mutants vs $17,667 \pm$ 2516 pixels in controls; $p=0.003$ ). Larger axonal trunks were found in the stroma and more $\mathrm{GFP}^{+}$axons in the plexus (Fig. $10 E, G)$. The abnormal density of $\mathrm{GFP}^{+}$axons was clearly visible after reslicing of the images. These obvious and severe branching defects were still seen at P14 $(n=3)$ both in the epithelial plexus $(156,667 \pm 20,816$ pixels vs $93,333 \pm 10,408$ pixels; $p=0.03)$ and in the stroma $(128,667 \pm 18,583$ pixels vs $41,667 \pm 4725$ pixels; $p=0.008)$ and in 2-month-old adult TAG-1:cre;Npn $1^{\text {lox/lox }}$ mice ( $n=6 ; 320,000 \pm 26,457$ pixels vs $148,333 \pm 12,583$ pixels in the epithelial plexus; $p=0.002 ; 202,667 \pm 16,623$ pixels vs 59,667 \pm 5507 pixels in the stroma; $p=0.003$; Fig. $10 I-L$ ). The presence of Tomato $^{+}$cells in the cornea of TAG-1:cre;Rosa ${ }^{\text {Tom }}$ (Fig. 3B) suggests that the axon branching defects observed in the cornea of TAG-1:cre; Npn $1^{\text {lox/lox }}$ mice could be at least to some extent attributed to abnormal cornea structure, although trigeminal axon branching defects are already observed before birth, when only a few Tomato ${ }^{+}$cells are present in TAG-1:cre; Rosa $^{\text {Tom }}$ mice (data not shown). To assess cornea cytoarchitecture, we used DAPI (see Materials and Methods) and quantified the number of superficial epithelial cells, basal epithelial cells, keratocytes (the only cells present in the stroma), and corneal thickness ( $n=3$ corneas for each genotype; Mann-Whitney test) in control and TAG-1:cre; $N p n 1^{\text {lox/lox }}$ mutants. The mean superficial epithelial cell density per $\mu \mathrm{m}^{2}$ was $647 \pm 69$ in mutants versus $625 \pm 60$ cells in controls $(p=0.85)$. The mean basal epithelial cells density per $\mu \mathrm{m}^{2}$ was $1607 \pm 147$ versus $1668 \pm 113$ cells $(p=0.78)$ in mutants and controls, respectively. The mean keratocyte density was $182 \pm 26$ versus $165 \pm 34$ cells $/ \mu \mathrm{m}^{2}(p=0.87)$ in mutant and control, respectively; and the mean corneal thickness was $87 \pm 10$ $\mu \mathrm{m}$ in mutants versus $92 \pm 11 \mu \mathrm{m}$ in controls $(p=0.91)$. To- gether, these results show that neuropilin-1 is a key regulator of trigeminal axon branching in the cornea.

\section{Discussion}

Our knowledge of the organization, ontogenesis, and remodeling of corneal innervation has primarily relied on immunolabeling methods. Here, we have tested 22 transgenic lines for their ability to induce the expression of one or multiple fluorescent proteins in corneal axons. We have identified 7 lines, including one BAC transgenic and 6 cre-recombinase driver lines, that efficiently label all or subsets of corneal axons. We further show that a combinatorial and dual expression of more than one fluorescent protein is possible by generating compound transgenic mice. Importantly, this genetic labeling method alleviates the problem of antibody penetration.

In the known "cornea nerve mouse lines" Trpm8:GFP and Thy1:YFP (Yu and Rosenblatt, 2007; Parra et al., 2010; Knowlton et al., 2013; Taylor-Clark et al., 2015), only a subset of corneal axons express a GFP. By contrast, the whole population of corneal axons could be labeled, using several of our cre-driver lines, as demonstrated by the perfect overlap with $\beta$ III-tubulin immunolabeling. This suggests that, in these lines, Cre is not only expressed in trigeminal projections but also probably in autonomic axons. In all cases, the fluorescent signal was high enough to be imaged directly indicating that it should be possible to image corneal axons in vivo and to perform time-lapse study of their development and response to injury. Importantly, we also identified lines that target a fraction of corneal nerves. The CGRP:GFP line will be very useful as it labels peptidergic nociceptors, which play a pivotal role in cornea pain (Belmonte et al., 2015). The Ret:cre ${ }^{E R}$ line is also particularly interesting as, at a low tamoxifen dose, a sparse labeling of a few corneal axons can be achieved. This is unique and will allow to image and reconstruct the arborization and branching pattern of single corneal axons and determine how it develops and respond to injury, inflammation, and other pathological conditions. Moreover, the morphology of nerve terminals we observed is consistent with a previous description of human corneal innervation (Marfurt et al., 2010), which reported terminals with single endings or more complex tree-like morphologies in the epithelium. Thus, the morphological heterogeneity we found in mice may also be present in humans.

Previous studies have suggested that, although corneal axons do not establish synaptic contacts in the cornea, they could release neuropeptides, such as CGRP and substance P, via vesicles resembling synaptic vesicles and expressing typical synaptic proteins (Kruger et al., 2003; Talbot and Kubilus, 2018). The presence of GFP ${ }^{+}$puncta in corneal axons of Wnt1 cre; Tau ${ }^{\text {SynGFP }}$ mice supports these findings. However, it could also just represent a diffusion of the vesicles containing the GFP fusion protein in the peripheral branch of trigeminal axons.

A deeper characterization of these new cornea nerve lines will require assessing their electrophysiological properties. For instance, it will be important to determine whether $A \delta$ fibers are labeled in these lines and whether their morphology differs from the C-fibers. Other lines that could also label corneal axons should also be studied, such as the Piezo2:GFP mice (Woo et al., 2015) and the TRPV1:cre line (Cavanaugh et al., 2011). Previous studies reported how mouse corneal nerve terminal density and number change during development (Wang et al., 2012; Reichard et al., 2016). More recently, a study shows the morphological and functional characteristics of corneal TRPM8-EYFP axons and how terminals appeared markedly altered in aged mice 
(Alcalde et al., 2018). Our study focuses on peptidergic CGRP ${ }^{+}$ axons and shows anatomic evidence for a significant decrease in corneal peptidergic nerve terminal density as a function of age in the mouse.

The morphological and functional modifications of cornealsensitive innervation with age are part of the general, senescenceinduced degenerative processes affecting primary sensory neurons, associated with DNA damage and oxidative stress (Long et al., 2014). These changes are likely reflected in morphometric, ultrastructural, and functional alterations of peripheral axons that, in the case of peripheral corneal nerves, may be accelerated by the slowdown in regeneration and remodeling of the nerve terminals that are needed to maintain the innervation of the rapidly turning over surface layers of the corneal epithelium (Alcalde et al., 2018). Interestingly, similar features were described in humans, and data from confocal microscopy demonstrated that corneal nerves (particularly sub-basal nerve density) exhibit pronounced reduction of corneal epithelial nerve terminals and sub-basal nerve fiber density with age (Niederer et al., 2007; He et al., 2010). Increased sub-basal nerve tortuosity has also been observed with age (Patel and McGhee, 2009).

An alternative measure of age-related corneal nerve changes is testing the functionality of corneal nerves. Using a CochetBonnet aesthesiometer to test A $\delta$ fiber mechanical sensitivity, corneal sensitivity seems to decrease gradually with age, beginning in the periphery and progressing centrally (Murphy et al., 2004; Roszkowska et al., 2004). Using the Belmonte noncontact aesthesiometer, which measures mechanical stimulation to $\mathrm{A} \delta$ fibers and C fibers as well as thermoreceptor and chemoreceptor sensitivity in C fibers, corneal sensitivity begins to decline in the second decade in patients, with major changes (presumably those registered by the Cochet-Bonnet aesthesiometer) becoming apparent by age 50 (Murphy et al., 2004). A reduction of the number and probably functional activity of peptidergic $\mathrm{CGRP}^{+}$axons probably contributes to dry eye disease observed in aged patients and to the development of accompanying unpleasant dryness sensations.

Previous studies have shown that chemorepulsive axon guidance cue semaphorin $3 \mathrm{~A}$ (Sema3A) and it receptors neuropilin-1 and plexin-A4 control the embryonic development of trigeminal axons (Yaron et al., 2005; Lwigale and Bronner-Fraser, 2007; Ko et al., 2010; McKenna et al., 2012). Sema3A, which is expressed in the developing cornea and lens, is thought to control the time course of cornea invasion by trigeminal axons. Interestingly, adult corneal axons are still responsive to Sema3A repulsive activity (Tanelian et al., 1997; Zhang et al., 2018). However, the postnatal development and adult patterning of corneal nerves in absence of Sema3A signaling have not been studied. Here we confirm that trigeminal axons prematurely invade the cornea in both neuropilin-1-deficient mice as observed in another Neuropilin-1 mutant line. We also show that, during postnatal development, the fasciculation and branching of corneal axons are strongly enhanced in both neuropilin-1 KOs. Corneal innervation defects are still present in adult neuropilin-1 KOs. As VEGF is able to bind neuropilin- 1 , it is possible that some of the defects seen in neuropilin-1 $\mathrm{KO}$ are also due to altered VEGF signaling in addition to Sema3A. However, the development of cornea itself does not seem to be affected in the TAG-1:cre; Npn $1^{\text {lox/lox }}$, which is consistent with other studies of another Neuropilin-1 mutant (McKenna et al., 2012), indicating that trigeminal axon branching defects are probably cell-autonomous. These genetic data confirm that Sema3A/neuropilin-1 are interesting drug targets for corneal nerve regeneration (Omoto et al., 2012).

\section{References}

Abraira VE, Ginty DD (2013) The sensory neurons of touch. Neuron 79: 618-639. CrossRef Medline

Alamri A, Bron R, Brock JA, Ivanusic JJ (2015) Transient receptor potential cation channel subfamily $\mathrm{V}$ member 1 expressing corneal sensory neurons can be subdivided into at least three subpopulations. Front Neuroanat 9:71. CrossRef Medline

Alamri AS, Wood RJ, Ivanusic JJ, Brock JA (2018) The neurochemistry and morphology of functionally identified corneal polymodal nociceptors and cold thermoreceptors. PLoS One 13:e0195108. CrossRef Medline

Alcalde I, Îñigo-Portugués A, González-González O, Almaraz L, Artime E, Morenilla-Palao C, Gallar J, Viana F, Merayo-Lloves J, Belmonte C (2018) Morphological and functional changes in TRPM8-expressing corneal cold thermoreceptor neurons during aging and their impact on tearing in mice. J Comp Neurol 520:633-655. CrossRef Medline

Bai L, Lehnert BP, Liu J, Neubarth NL, Dickendesher TL, Nwe PH, Cassidy C, Woodbury CJ, Ginty DD (2015) Genetic identification of an expansive mechanoreceptor sensitive to skin stroking. Cell 163:1783-1795. CrossRef Medline

Bautista DM, Siemens J, Glazer JM, Tsuruda PR, Basbaum AI, Stucky CL, Jordt SE, Julius D (2007) The menthol receptor TRPM8 is the principal detector of environmental cold. Nature 448:204-208. CrossRef Medline

Belle M, Godefroy D, Dominici C, Heitz-Marchaland C, Zelina P, Hellal F, Bradke F, Chédotal A (2014) A simple method for 3D analysis of immunolabeled axonal tracts in a transparent nervous system. Cell Rep 9:11911201. CrossRef Medline

Belmonte C, Gallar J, Pozo MA, Rebollo I (1991) Excitation by irritant chemical substances of sensory afferent units in the cat's cornea. J Physiol 437:709-725. CrossRef Medline

Belmonte C, Acosta MC, Merayo-Lloves J, Gallar J (2015) What causes eye pain? Curr Ophthalmol Rep 3:111-121. CrossRef Medline

Brissette-Storkus CS, Reynolds SM, Lepisto AJ, Hendricks RL (2002) Identification of a novel macrophage population in the normal mouse corneal stroma. Invest Ophthalmol Vis Sci 43:2264-2271. Medline

Bron R, Wood RJ, Brock JA, Ivanusic JJ (2014) Piezo2 expression in corneal afferent neurons. J Comp Neurol 522:2967-2979. CrossRef Medline

Canner JP, Linsenmayer TF, Kubilus JK (2014) Developmental regulation of trigeminal TRPA1 by the cornea. Invest Ophthalmol Vis Sci 56:29-36. CrossRef Medline

Caterina MJ, Schumacher MA, Tominaga M, Rosen TA, Levine JD, Julius D (1997) The capsaicin receptor: a heat-activated ion channel in the pain pathway. Nature 389:816-824. CrossRef Medline

Cavanaugh DJ, Chesler AT, Jackson AC, Sigal YM, Yamanaka H, Grant R, O'Donnell D, Nicoll RA, Shah NM, Julius D, Basbaum AI (2011) Trpvl reporter mice reveal highly restricted brain distribution and functional expression in arteriolar smooth muscle cells. J Neurosci 31:5067-5077. CrossRef Medline

Chatzopoulou E, Miguez A, Savvaki M, Levasseur G, Muzerelle A, Muriel MP, Goureau O, Watanabe K, Goutebroze L, Gaspar P, Zalc B, Karagogeos D, Thomas JL (2008) Structural requirement of TAG-1 for retinal ganglion cell axons and myelin in the mouse optic nerve. J Neurosci 28:7624-7636. CrossRef Medline

Chucair-Elliott AJ, Zheng M, Carr DJ (2015) Degeneration and regeneration of corneal nerves in response to HSV-1 infection. Invest Ophthalmol Vis Sci 56:1097-1107. CrossRef Medline

Coppola E, d'Autréaux F, Rijli FM, Brunet JF (2010) Ongoing roles of Phox2 homeodomain transcription factors during neuronal differentiation. Development 137:4211-4220. CrossRef Medline

Coste B, Mathur J, Schmidt M, Earley TJ, Ranade S, Petrus MJ, Dubin AE, Patapoutian A (2010) Piezol and Piezo2 are essential components of distinct mechanically activated cation channels. Science 330:55-60. CrossRef Medline

Danielian PS, Muccino D, Rowitch DH, Michael SK, McMahon AP (1998) Modification of gene activity in mouse embryos in utero by a tamoxifeninducible form of Cre recombinase. Curr Biol 8:1323-1332. CrossRef Medline

de Castro F, Silos-Santiago I, López de Armentia M, Barbacid M, Belmonte C (1998) Corneal innervation and sensitivity to noxious stimuli in trk A knockout mice. Eur J Neurosci 10:146-152. CrossRef Medline

Deckelbaum RA, Holmes G, Zhao Z, Tong C, Basilico C, Loomis CA (2012) Regulation of cranial morphogenesis and cell fate at the neural crest- 
mesoderm boundary by engrailed 1. Development 139:1346-1358. CrossRef Medline

Ehmke T, Leckelt J, Reichard M, Weiss H, Hovakimyan M, Heisterkamp A, Stachs O, Baltrusch S (2016) In vivo nonlinear imaging of corneal structures with special focus on BALB/c and streptozotocin-diabetic Thy1-YFP mice. Exp Eye Res 146:137-144. CrossRef Medline

Espinosa-Medina I, Outin E, Picard CA, Chettouh Z, Dymecki S, Consalez GG, Coppola E, Brunet JF (2014) Neurodevelopment: parasympathetic ganglia derive from Schwann cell precursors. Science 345:87-90. CrossRef Medline

Esposito MS, Capelli P, Arber S (2014) Brainstem nucleus MdV mediates skilled forelimb motor tasks. Nature 508:351-356. CrossRef Medline

Evans AL, Gage PJ (2005) Expression of the homeobox gene Pitx2 in neural crest is required for optic stalk and ocular anterior segment development. Hum Mol Genet 14:3347-3359. CrossRef Medline

Furley AJ, Morton SB, Manalo D, Karagogeos D, Dodd J, Jessell TM (1990) The axonal glycoprotein TAG-1 is an immunoglobulin superfamily member with neurite outgrowth-promoting activity. Cell 61:157-170. CrossRef Medline

Gage PJ, Rhoades W, Prucka SK, Hjalt T (2005) Fate maps of neural crest and mesoderm in the mammalian eye. Invest Ophthalmol Vis Sci 46: 4200-4208. CrossRef Medline

Gong S, Zheng C, Doughty ML, Losos K, Didkovsky N, Schambra UB, Nowak NJ, Joyner A, Leblanc G, Hatten ME, Heintz N (2003) A gene expression atlas of the central nervous system based on bacterial artificial chromosomes. Nature 425:917-925. CrossRef Medline

González-González O, Bech F, Gallar J, Merayo-Lloves J, Belmonte C (2017) Functional properties of sensory nerve terminals of the mouse cornea. Invest Ophthalmol Vis Sci 58:404-415. CrossRef Medline

Gu C, Rodriguez ER, Reimert DV, Shu T, Fritzsch B, Richards LJ, Kolodkin AL, Ginty DD (2003) Neuropilin-1 conveys semaphorin and VEGF signaling during neural and cardiovascular development. Dev Cell 5:45-57. CrossRef Medline

Guo C, Yang W, Lobe CG (2002) A Cre recombinase transgene with mosaic, widespread tamoxifen-inducible action. Genesis 32:8-18. CrossRef Medline

He J, Bazan HE (2016) Neuroanatomy and neurochemistry of mouse cornea. Invest Ophthalmol Vis Sci 57:664-674. CrossRef Medline

He J, Bazan NG, Bazan HE (2010) Mapping the entire human corneal nerve architecture. Exp Eye Res 91:513-523. CrossRef Medline

Hippenmeyer S, Vrieseling E, Sigrist M, Portmann T, Laengle C, Ladle DR, Arber S (2005) A developmental switch in the response of DRG neurons to ETS transcription factor signaling. PLoS Biol 3:e159. CrossRef Medline

Ivanusic JJ, Wood RJ, Brock JA (2013) Sensory and sympathetic innervation of the mouse and guinea pig corneal epithelium. J Comp Neurol 521:877893. CrossRef Medline

Jones MA, Marfurt CF (1991) Calcitonin gene-related peptide and corneal innervation: a developmental study in the rat. J Comp Neurol 313:132150. CrossRef Medline

Kimmel RA, Turnbull DH, Blanquet V, Wurst W, Loomis CA, Joyner AL (2000) Two lineage boundaries coordinate vertebrate apical ectodermal ridge formation. Genes Dev 14:1377-1389. CrossRef Medline

Kitsukawa T, Shimizu M, Sanbo M, Hirata T, Taniguchi M, Bekku Y, Yagi T, Fujisawa H (1997) Neuropilin-semaphorin III/D-mediated chemorepulsive signals play a crucial role in peripheral nerve projection in mice. Neuron 19:995-1005. CrossRef Medline

Knowlton WM, Palkar R, Lippoldt EK, McCoy DD, Baluch F, Chen J, McKemy DD (2013) A sensory-labeled line for cold: TRPM8-expressing sensory neurons define the cellular basis for cold, cold pain, and coolingmediated analgesia. J Neurosci 33:2837-2848. CrossRef Medline

Ko JA, Mizuno Y, Yanai R, Chikama T, Sonoda KH (2010) Expression of semaphorin $3 \mathrm{~A}$ and its receptors during mouse corneal development. Biochem Biophys Res Commun 403:305-309. CrossRef Medline

Kruger L, Light AR, Schweizer FE (2003) Axonal terminals of sensory neurons and their morphological diversity. J Neurocytol 32:205-216. CrossRef Medline

Lele P, Weddell G (1959) Sensory nerves of the cornea and cutaneous sensibility. Exp Neurol 1:334-359. CrossRef Medline

Le Pichon CE, Chesler AT (2014) The functional and anatomical dissection of somatosensory subpopulations using mouse genetics. Front Neuroanat 8:21. CrossRef Medline

Li L, Rutlin M, Abraira VE, Cassidy C, Kus L, Gong S, Jankowski MP, Luo W,
Heintz N, Koerber HR, Woodbury CJ, Ginty DD (2011) The functional organization of cutaneous low-threshold mechanosensory neurons. Cell 147:1615-1627. CrossRef Medline

Livet J, Weissman TA, Kang H, Draft RW, Lu J, Bennis RA, Sanes JR, Lichtman JW (2007) Transgenic strategies for combinatorial expression of fluorescent proteins in the nervous system. Nature 450:56-62. CrossRef Medline

Long YC, Tan TM, Takao I, Tang BL (2014) The biochemistry and cell biology of aging: metabolic regulation through mitochondrial signaling. Am J Physiol Endocrinol Metab 306:E581-E591. CrossRef Medline

Luo W, Enomoto H, Rice FL, Milbrandt J, Ginty DD (2009) Molecular identification of rapidly adapting mechanoreceptors and their developmental dependence on ret signaling. Neuron 64:841-856. CrossRef Medline

Lwigale PY, Bronner-Fraser M (2007) Lens-derived Semaphorin3A regulates sensory innervation of the cornea. Dev Biol 306:750-759. CrossRef Medline

Madisen L, Zwingman TA, Sunkin SM, Oh SW, Zariwala HA, Gu H, Ng LL, Palmiter RD, Hawrylycz MJ, Jones AR, Lein ES, Zeng H (2010) A robust and high-throughput Cre reporting and characterization system for the whole mouse brain. Nat Neurosci 13:133-140. CrossRef Medline

Marfurt CF (1988) Sympathetic innervation of the rat cornea as demonstrated by the retrograde and anterograde transport of horseradish peroxidase-wheat germ agglutinin. J Comp Neurol 268:147-160. CrossRef Medline

Marfurt CF, Ellis LC (1993) Immunohistochemical localization of tyrosine hydroxylase in corneal nerves. J Comp Neurol 336:517-531. CrossRef Medline

Marfurt CF, Kingsley RE, Echtenkamp SE (1989) Sensory and sympathetic innervation of the mammalian cornea: a retrograde tracing study. Invest Ophthalmol Vis Sci 30:461-472. Medline

Marfurt CF, Murphy CJ, Florczak JL (2001) Morphology and neurochemistry of canine corneal innervation. Invest Ophthalmol Vis Sci 42:22422251. Medline

Marfurt CF, Cox J, Deek S, Dvorscak L (2010) Anatomy of the human corneal innervation. Exp Eye Res 90:478-492. CrossRef Medline

McKenna CC, Munjaal RP, Lwigale PY (2012) Distinct roles for Neuropilin1 and Neuropilin2 during mouse corneal innervation. PLoS One 7:e37175. CrossRef Medline

Meng H, Yuan Y, Lee VM (2011) Loss of sphingosine kinase 1/S1P signaling impairs cell growth and survival of neurons and progenitor cells in the developing sensory ganglia. PLoS One 6:e27150. CrossRef Medline

Merte J, Wang Q, Vander Kooi CW, Sarsfield S, Leahy DJ, Kolodkin AL, Ginty DD (2010) A forward genetic screen in mice identifies Sema3AK108N, which binds to neuropilin-1 but cannot signal. J Neurosci 30:5767-5775. CrossRef Medline

Müller LJ, Marfurt CF, Kruse F, Tervo TM (2003) Corneal nerves: structure, contents and function. Exp Eye Res 76:521-542. CrossRef Medline

Murata Y, Masuko S (2006) Peripheral and central distribution of TRPV1, substance P and CGRP of rat corneal neurons. Brain Res 1085:87-94. CrossRef Medline

Murphy PJ, Patel S, Kong N, Ryder RE, Marshall J (2004) Noninvasive assessment of corneal sensitivity in young and elderly diabetic and nondiabetic subjects. Invest Ophthalmol Vis Sci 45:1737-1742. CrossRef Medline

Nakamura A, Hayakawa T, Kuwahara S, Maeda S, Tanaka K, Seki M, Mimura O (2007) Morphological and immunohistochemical characterization of the trigeminal ganglion neurons innervating the cornea and upper eyelid of the rat. J Chem Neuroanat 34:95-101. CrossRef Medline

Namavari A, Chaudhary S, Sarkar J, Yco L, Patel K, Han KY, Yue BY, Chang $\mathrm{JH}$, Jain S (2011) In vivo serial imaging of regenerating corneal nerves after surgical transection in transgenic Thyl-YFP mice. Invest Ophthalmol Vis Sci 52:8025-8032. CrossRef Medline

Niederer RL, Perumal D, Sherwin T, McGhee CN (2007) Age-related differences in the normal human cornea: a laser scanning in vivo confocal microscopy study. Br J Ophthalmol 91:1165-1169. CrossRef Medline

Omoto M, Yoshida S, Miyashita H, Kawakita T, Yoshida K, Kishino A, Kimura T, Shibata S, Tsubota K, Okano H, Shimmura S (2012) The semaphorin 3A inhibitor SM-345431 accelerates peripheral nerve regeneration and sensitivity in a murine corneal transplantation model. PLoS One 7:e47716. CrossRef Medline

Parra A, Madrid R, Echevarria D, del Olmo S, Morenilla-Palao C, Acosta MC, Gallar J, Dhaka A, Viana F, Belmonte C (2010) Ocular surface wetness is 
regulated by TRPM8-dependent cold thermoreceptors of the cornea. Nat Med 16:1396-1399. CrossRef Medline

Patel DV, McGhee CN (2009) In vivo confocal microscopy of human corneal nerves in health, in ocular and systemic disease, and following corneal surgery: a review. Br J Ophthalmol 93:853-860. CrossRef Medline

Pecho-Vrieseling E, Sigrist M, Yoshida Y, Jessell TM, Arber S (2009) Specificity of sensory-motor connections encoded by Sema3e-Plxnd1 recognition. Nature 459:842-846. CrossRef Medline

Preibisch S, Saalfeld S, Tomancak P (2009) Globally optimal stitching of tiled 3D microscopic image acquisitions. Bioinformatics 25:1463-1465. CrossRef Medline

Quallo T, Vastani N, Horridge E, Gentry C, Parra A, Moss S, Viana F, Belmonte C, Andersson DA, Bevan S (2015) TRPM8 is a neuronal osmosensor that regulates eye blinking in mice. Nat Commun 6:7150. CrossRef Medline

Ranade SS, Woo SH, Dubin AE, Moshourab RA, Wetzel C, Petrus M, Mathur J, Bégay V, Coste B, Mainquist J, Wilson AJ, Francisco AG, Reddy K, Qiu Z, Wood JN, Lewin GR, Patapoutian A (2014) Piezo2 is the major transducer of mechanical forces for touch sensation in mice. Nature 516:121125. CrossRef Medline

Reichard M, Hovakimyan M, Guthoff RF, Stachs O (2014) In vivo visualisation of murine corneal nerve fibre regeneration in response to ciliary neurotrophic factor. Exp Eye Res 120:20-27. CrossRef Medline

Reichard M, Weiss H, Poletti E, Ruggeri A, Guthoff RF, Stachs O, Baltrusch S (2016) Age-related changes in murine corneal nerves. Curr Eye Res 41: 1021-1028. CrossRef Medline

Roszkowska AM, Colosi P, Ferreri FM, Galasso S (2004) Age-related modifications of corneal sensitivity. Ophthalmologica 218:350-355. CrossRef Medline

Rózsa AJ, Beuerman RW (1982) Density and organization of free nerve endings in the corneal epithelium of the rabbit. Pain 14:105-120. CrossRef Medline

Rutlin M, Ho CY, Abraira VE, Cassidy C, Bai L, Woodbury CJ, Ginty DD (2014) The cellular and molecular basis of direction selectivity of A $\delta$ LTMRs. Cell 159:1640-1651. CrossRef Medline

Schmidt ER, Brignani S, Adolfs Y, Lemstra S, Demmers J, Vidaki M, Donahoo AS, Lilleväli K, Vasar E, Richards LJ, Karagogeos D, Kolk SM, Pasterkamp RJ (2014) Subdomain-mediated axon-axon signaling and chemoattraction cooperate to regulate afferent innervation of the lateral habenula. Neuron 83:372-387. CrossRef Medline

Seal RP, Wang X, Guan Y, Raja SN, Woodbury CJ, Basbaum AI, Edwards RH (2009) Injury-induced mechanical hypersensitivity requires C-low threshold mechanoreceptors. Nature 462:651-655. CrossRef Medline

Shimizu T, Toriumi H, Sato H, Shibata M, Nagata E, Gotoh K, Suzuki N (2007) Distribution and origin of TRPV1 receptor-containing nerve fibers in the dura mater of rat. Brain Res 1173:84-91. CrossRef Medline

Steventon B, Mayor R, Streit A (2014) Neural crest and placode interaction during the development of the cranial sensory system. Dev Biol 389:2838. CrossRef Medline

Sun Y, Dykes IM, Liang X, Eng SR, Evans SM, Turner EE (2008) A central role for Isletl in sensory neuron development linking sensory and spinal gene regulatory programs. Nat Neurosci 11:1283-1293. CrossRef Medline

Talbot CJ, Kubilus JK (2018) Developmental analysis of SV2 in the embry- onic chicken corneal epithelium. Exp Eye Res 172:137-143. CrossRef Medline

Tanelian DL, Barry MA, Johnston SA, Le T, Smith GM (1997) Semaphorin III can repulse and inhibit adult sensory afferents in vivo. Nat Med 3:1398-1401. CrossRef Medline

Taylor-Clark TE, Wu KY, Thompson JA, Yang K, Bahia PK, Ajmo JM (2015) Thy1.2 YFP-16 transgenic mouse labels a subset of large-diameter sensory neurons that lack TRPV1 expression. PLoS One 10:1-16. CrossRef Medline

Traka M, Dupree JL, Popko B, Karagogeos D (2002) The neuronal adhesion protein TAG-1 is expressed by Schwann cells and oligodendrocytes and is localized to the juxtaparanodal region of myelinated fibers. J Neurosci 22:3016-3024. CrossRef Medline

Ulupinar E, Datwani A, Behar O, Fujisawa H, Erzurumlu R (1999) Role of semaphorin III in the developing rodent trigeminal system. Mol Cell Neurosci 13:281-292. CrossRef Medline

Wang C, Fu T, Xia C, Li Z (2012) Changes in mouse corneal epithelial innervation with age. Invest Ophthalmol Vis Sci 53:5077-5084. CrossRef Medline

Woo SH, Lukacs V, de Nooij JC, Zaytseva D, Criddle CR, Francisco A, Jessell TM, Wilkinson KA, Patapoutian A (2015) Piezo2 is the principal mechanotransduction channel for proprioception. Nat Neurosci 18: 1756-1762. CrossRef Medline

Yang L, Cai CL, Lin L, Qyang Y, Chung C, Monteiro RM, Mummery CL, Fishman GI, Cogen A, Evans S (2006) Isl1Cre reveals a common bmp pathway in heart and limb development. Development 133:1575-1585. CrossRef Medline

Yaron A, Huang PH, Cheng HJ, Tessier-Lavigne M (2005) Differential requirement for plexin-A3 and -A4 in mediating responses of sensory and sympathetic neurons to distinct class 3 semaphorins. Neuron 45:513-523. CrossRef Medline

Young KM, Psachoulia K, Tripathi RB, Dunn SJ, Cossell L, Attwell D, Tohyama K, Richardson WD (2013) Oligodendrocyte dynamics in the healthy adult CNS: evidence for myelin remodeling. Neuron 77:873-885. CrossRef Medline

Yu CQ, Rosenblatt MI (2007) Transgenic corneal neurofluorescence in mice: a new model for in vivo investigation of nerve structure and regeneration. Invest Ophthalmol Vis Sci 48:1535-1542. CrossRef Medline

Zander E, Weddell G (1951) Observations on the innervation of the cornea. J Anat 85:68-99. Medline

Zhang M, Zhou Q, Luo Y, Nguyen T, Rosenblatt MI, Guaiquil VH (2018) Semaphorin3A induces nerve regeneration in the adult cornea: a switch from its repulsive role in development. PLoS One 13:1-16. CrossRef Medline

Zhong SC, Chen XS, Cai QY, Luo X, Chen XH, Liu J, Yao ZX (2010) Dynamic expression and heterogeneous intracellular location of En-1 during late mouse embryonic development. Cells Tissues Organs 191:289-300. CrossRef Medline

Zimmerman A, Bai L, Ginty DD (2014) The gentle touch receptors of mammalian skin. Science 346:950-954. CrossRef Medline

Zylka MJ, Rice FL, Anderson DJ (2005) Topographically distinct epidermal nociceptive circuits revealed by axonal tracers targeted to Mrgprd. Neuron 45:17-25. CrossRef Medline 